\title{
Mesozoic deposits of SW Gondwana (Namibia): unravelling Gondwanan sedimentary dispersion drivers by detrital zircon
}

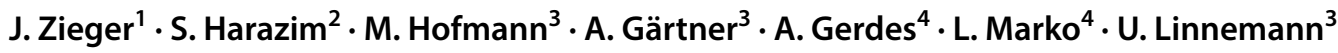

Received: 15 January 2020 / Accepted: 3 April 2020 / Published online: 25 April 2020

(c) The Author(s) 2020

\begin{abstract}
The Namibian Mesozoic successions may be remnant of a high dynamic sedimentary system that is characterized by multiple stages of sediment accumulation and erosion with contemporaneous homogenization starting with the deposition of the Permo-Carboniferous Dwyka Group strata and continues at least until the Lower Cretaceous. The Lower Cretaceous sedimentary system is interpreted to have involved at least an area covering the whole SW Gondwana, documenting the sedimentary history during the evolution from an ice house environment to an arid desert. To test the sediment homogenization hypothesis, we applied a combination of isotopic and morphometric data on detrital zircon grains, as well as whole-rock geochemical data of selected Mesozoic sandstones from Namibia. As a base for the interpretation of the detrital zircon age data we compiled a zircon age dataset with c. 44,000 analyses for the southern African region. All samples reveal a major detrital pan-African zircon age peak of c. $0.5-0.7 \mathrm{Ga}$ sourced from the pan-African magmatic events occurring around the Kalahari Craton margin. The lowermost Triassic is characterized by the occurrence of additional Mesoproterozoic and Paleoproterozoic age peaks of c. 1.0-1.2 Ga and 1.8-2.0 Ga with a majority of zircon grains showing angular shapes. The protosource of these grains is interpreted to possibly be the Namaqua Metamorphic Complex and other Paleoproterozoic structural units deformed in course of the Namaqua orogeny. In contrast, other samples show a prominent Permo-Triassic age peak and completely rounded zircon grains, putatively derived from within the Gondwanides volcanic arc. The disparity in the zircon age pattern may point towards a change in provenance and also a change in the whole system of zircon recycling during the Mesozoic southern Gondwana. The Lower Triassic Neu Loore fm. are constrained to more local bedrock sources and short zircon transport distance. In contrast, zircon grains of the Middle Triassic Omingonde, the Jurassic Etjo und the Cretaceous Twyfelfontein formations are an expression for a major recycling and sediment homogenization system. The system was facilitated by an interplay between fluvial and eolian sedimentary transport systems.
\end{abstract}

Keywords Zircon U-pb · Mesozoic · Gondwana $\cdot$ Karoo $\cdot$ Namibia

Electronic supplementary material The online version of this article (https://doi.org/10.1007/s00531-020-01864-2) contains supplementary material, which is available to authorized users.

\section{J. Zieger}

johannes.zieger@senckenberg.de

1 Senckenberg Museum für Naturkunde Görlitz, Am Museum 1, 02826 Görlitz, Germany

2 TU Dresden, Fakultät Umweltwissenschaften, Institut für Geographie, Helmholtzstr. 10, 01069 Dresden, Germany

3 Senckenberg Naturhistorische Sammlungen Dresden, Museum für Mineralogie und Geologie, Königsbrücker Landstr. 159, 01109 Dresden, Germany

4 Institut für Geowissenschaften, Mineralogie, Goethe Universität Frankfurt, Altenhoeferallee 1, 60438 Frankfurt, Germany

\section{Introduction}

The Karoo sedimentary strata of southern Africa are remnants of basin fills confined to the supercontinent of Gondwana existing during the late Paleozoic to the early Mesozoic (e.g. Catuneanu et al. 2005). The period, called 'Karoo-age', is characterised by the presence of late Paleozoic to early Mesozoic basins across southern and southwestern Gondwana (Fig. 1a). Although the subduction direction along the southern Gondwanan margin is not clear (Winter 1984), most workers agree that the tectonic regime during the late Paleozoic was characterized by a north-dipping subduction, accretion and shortening along the southwestern Gondwanan margin (e.g. Lindeque et al. 2012; Stollhofen et al. 2000; Viglietti et al. 2017), producing the Gondwanides orogen 


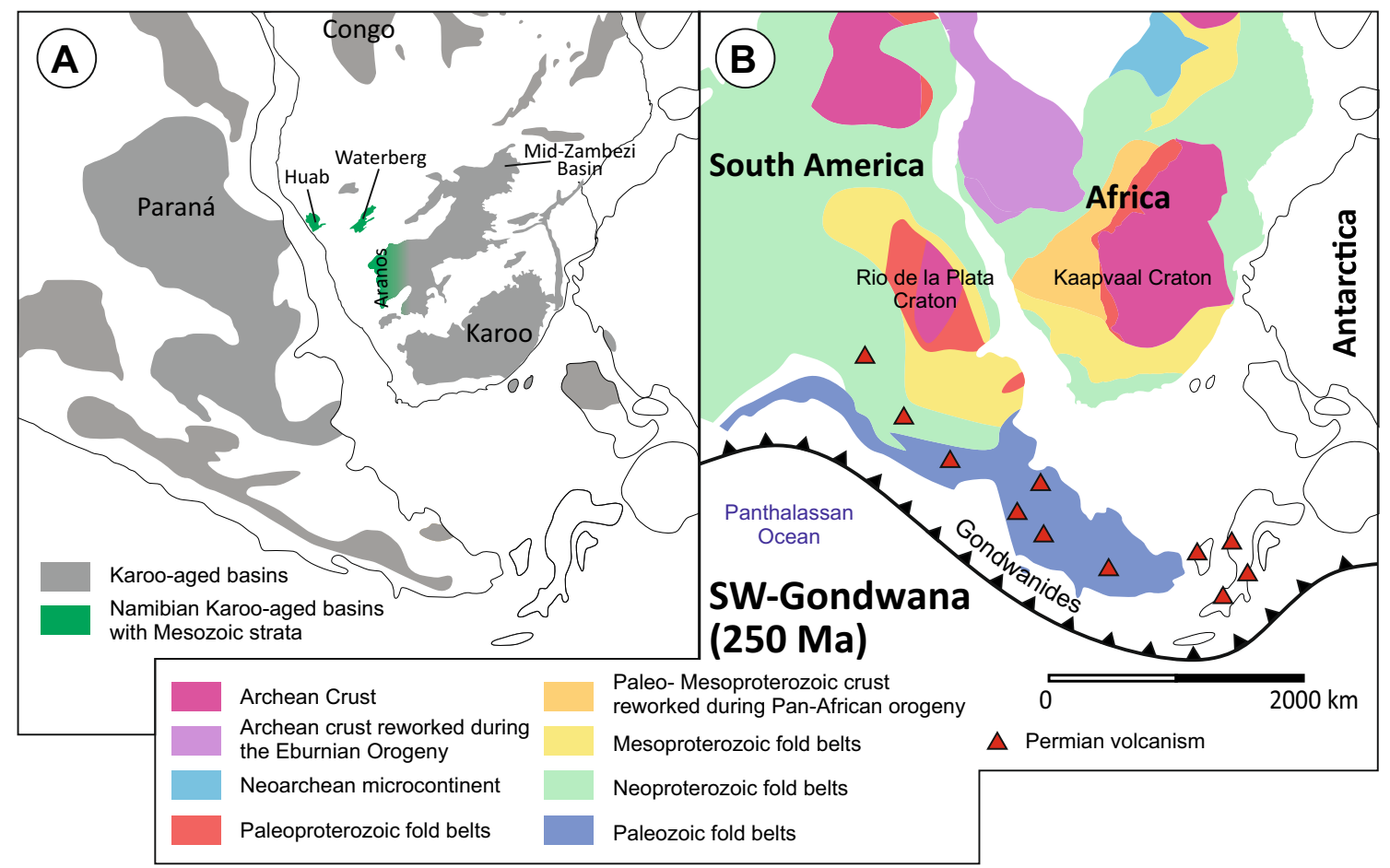

Fig. 1 Generalized maps of southern Gondwana during the PermoTriassic transition. a Distribution of Karoo-aged strata in southern Gondwana (map based on Isbell et al. 2008; Visser 1983). b Conti-

(Ramos and Aleman 2000), with a Carboniferous-to-Permian volcanic arc in Northern Patagonia (Fig. 1b). The interaction of different scenarios on Gondwanan convergent and divergent margins led to the formation of distinct basin types across today's Africa and South America resting on Paleoand Mesoproterozoic crust belonging to the Kaapvaal Craton as well as on Neoproterozoic fold belts (Fig. 1b). With the end of the Paleozoic the amalgamation of Pangea was complete (Ramos 2008). As subjected to continuous subduction, the supercontinent became unstable (Lovecchio et al. 2020; and references therein). In the Mesozoic negative inversion affected compressed structures, due to an extensional stress regime (Williams et al. 1989). The tectonic situation lasted at least until early Cretaceous times and was terminated by the beginning Gondwana break-up or are still present today (Viola et al. 2012). In the Mesozoic fluvio-eolian accumulations of sub-humid to semiarid environments developed in the Middle-Late Triassic, reaching a maximum aridity in the Lower Cretaceous period (Scherer and Goldberg 2007; Scherer and Lavina 2005; Stanistreet and Stollhofen 1999).

$\mathrm{The} \mathrm{U}-\mathrm{Pb}$ and $\mathrm{Hf}$ isotopic composition of detrital zircon grains of clastic sediments allows the identification and characterization of possible sedimentary source areas and provides information concerning paleogeography, sediment-dispersal patterns and sediment reworking (e.g. Dickinson et al. 1983; Gehrels et al. 2000; Ross nent configuration at c. $250 \mathrm{Ma}$ and structural units of South America and southern Africa (map based on Isbell et al. 2008; Pagani and Taboada 2010; Pankhurst et al. 2006)

et al. 1992). Up to date, little progress has been made, regarding detrital zircon studies dealing with Namibian Karoo-aged successions in the studied area (Jansson 2010; Zieger et al. 2019). The lack of provenance studies on other southern African Paleozoic to Mesozoic strata is also apparent (Andersen et al. 2016b; Bowden 2013; Veevers and Saeed 2007; Viglietti et al. 2018), which in contrast to the importance of the Karoo-aged sediments, as they may play a central role in the integrated recycling model for the southern African region proposed by Andersen et al. (2019b), questioning classic source-to-sink dynamics.

The primary aim of this study was to test the hypothesis of long term storage of recycled material within continental basins and how to identify the process. To reveal sedimentary transport processes and potential provenance areas of Gondwana in Mesozoic times, seven siliciclastic fluviatile and eolian sediment samples were collected from the Neu Loore, Omingonde, Etjo and Twyfelfontein formation successions of the Aranos, Waterberg and Huab basins, Namibia, as they cover a variety of fluvial to eolian facies. The samples were investigated with respect to their zircon age distribution pattern as well as to their morphological features. Based on detrital zircon features we proposed a tool set for distinguishing recycling intensities which the respective strata underwent, using LA-ICP-MS 
$\mathrm{U}-\mathrm{Pb}$ and $\mathrm{La}-\mathrm{Hf}$ dating techniques, whole-rock geochemistry and detrital zircon morphology.

As of the absence of datable ash layers, the ages of the uppermost Karoo-aged successions are poorly constrained. Not being able to time Mesozoic sediment accumulation events is in contrast to the importance of the sediments as records for their source area locations, erosional processes and sediment transport during the final phase of Gondwana existence. Therefore, our second aim was to constrain the maximum deposition ages to time potential changes in the sediment recycling pattern.

\section{Geological background}

\section{Evolution of the southwestern Gondwanan Mesozoic successions}

During the Carboniferous/Permian transition NW- to NEstriking graben to half-graben structures developed in southern Gondwana (Ring 1995; Stollhofen et al. 2000), interpreted as an early intracontinental rift. At the same time, the Dwyka glaciation took place at the southern Gondwana region located at high latitudes (e.g. Bullard et al. 1965), which was accompanied by the sedimentation of Karoo-aged basin successions all over southwestern Gondwana (e.g. Visser 1989; Fig. 1a). Deglaciation and ice sheet collapse was induced by a continuous northward drift of southwestern Gondwana out of the polar and sub-polar regions towards lower latitudes (Visser 1995), causing intense sedimentary recycling of older strata (Zieger et al. 2019). Cold, wet conditions prevailed at least during the early Permian, enabling the occurrence of peat deposits, which developed at the fluviodeltaic basin margins (Miller 2008). The basin evolution was facilitated by several alternating regression and transgression cycles of an inland sea (Visser 1992) and prevailing sedimentary recycling conditions (Andersen et al. 2016b). These cycles are different within the Karoo-aged basin strata: For example, the successions of the Namibian Aranos Basin are thought to show three transgression-regression cycles whereas such cycles are not recorded within the sedimentary rocks of the more northward located Namibian Waterberg Basin (Bangert 2000; Grill 1997; Heath 1972; Smith and Swart 2002).

The continuous northward drift brought the southern Gondwanan region to lower latitudes with distinctive seasonal climates during the mid-Permian accompanied by the occurrence of red bed successions (Scheffler et al. 2006; Turner 1999). The drift into subtropical regions and contemporaneous subduction of the Nazca plate underneath the South American plate resulted in the uplift of the Andean mountain belt, which led to a reduction in water supply and finally let the inland sea shrink to small isolated lakes
(Fig. 2a; Visser 1995). Permian to Triassic uplift, gentle tilting and erosional processes denudated the Permian aged sediments under warm humid conditions leading to a low angular angle unconformity (Visser 1995). During these transitional phases, Gondwana showed signs of crustal extension as the southern margin of the supercontinent underwent shortening due to the subduction of the paleoPacific plate (Stanistreet and Stollhofen 1999). Consequent subsidence caused the deposition of Triassic strata in
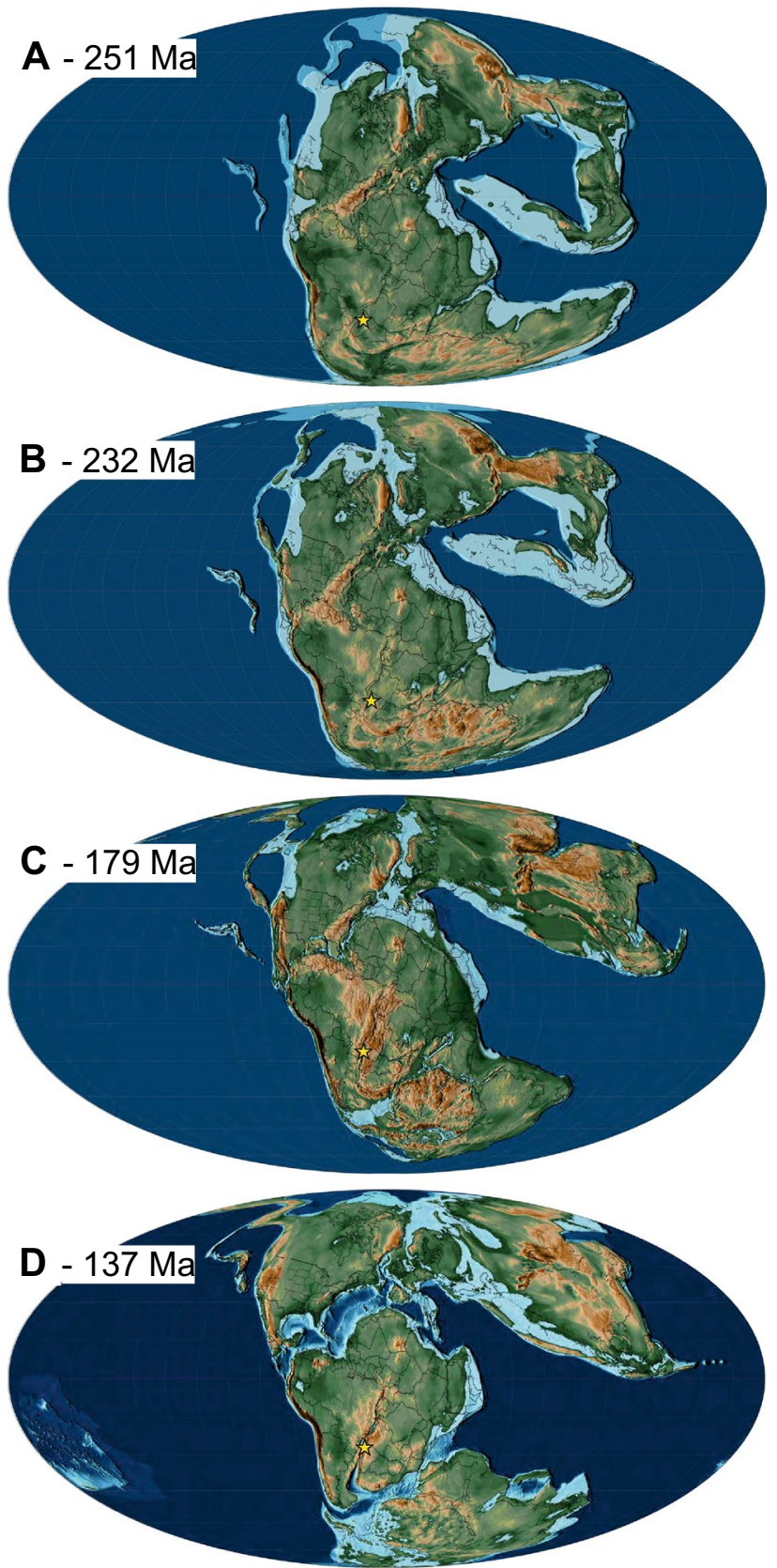

Fig. 2 a-d Paleogeographic reconstructions for the time period from 251 to 137 Ma (modified from Scotese 2014a; Scotese 2014b, c). The yellow star marks the study area 
southern Africa (e.g. Neu Loore fm., Namibia; Mosolotsane fm., Botswana; Molteno and Elliot formations, South Africa) (Miller 2008). The sedimentation of these continental successions was recorded by meandering rivers and numerous water bodies (Visser 1995). Along with the evolution, Permian sediments became eroded and mixed with considerable amounts of Permo-Triassic ash-fall tuffs (Viglietti et al. 2018).

During the Upper Triassic warm, semi-arid conditions characterized southwestern Gondwana (Visser 1995). Small basins (e.g. Omingonde fm., Waterberg Basin, Figs. 1b, 3b, 4) developed due to deepening halfgraben
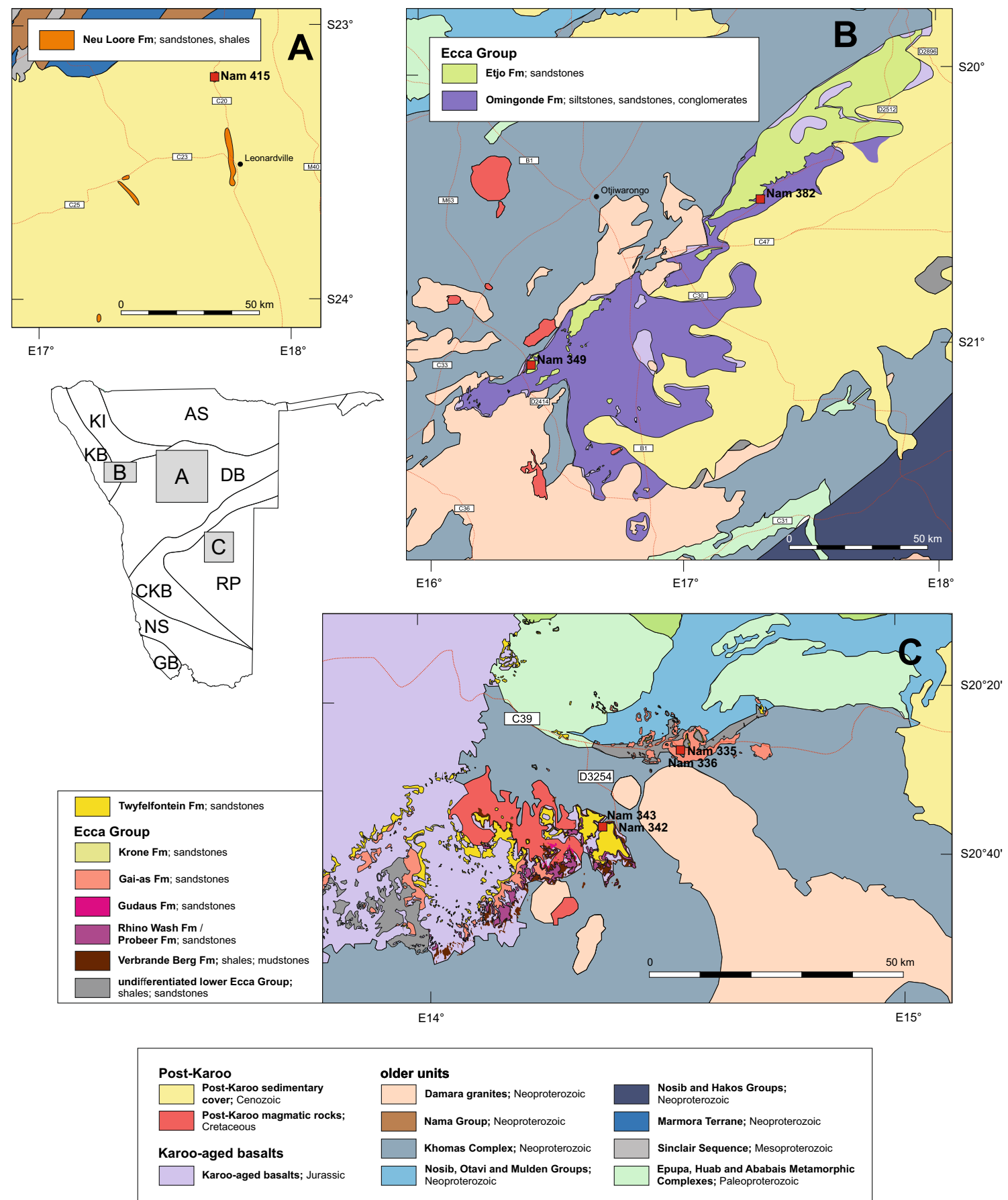

Fig. 3 Geological maps of the Neu Loore fm. (a), Waterberg Basin (b), Huab Basin (c), and outcrop regions with indicated sampling locations modified after Miller (1988), Miller (2008), Schreiber (2002), Schreiber (2006a, b) and Milner (2007). Simplified map of
Namibian basement complexes McCourt et al. (2013). AS Angola Shield, $K I$ Kamanjab Inlier, $K B$ Kaoko Belt, $D B$ Damara Belt, $C K B$ Choma-Kaloma Block, $R P$ Rehoboth Province, NS Namaqua Sector, $G B$ Gariep Belt 


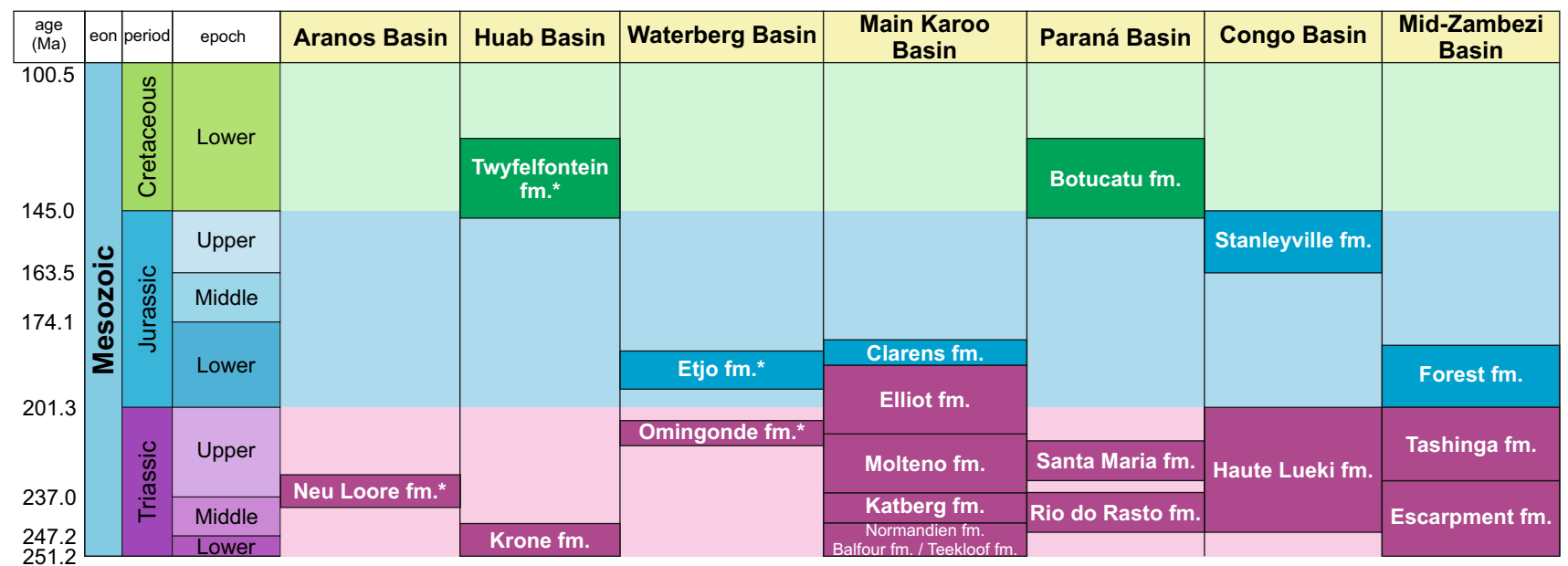

Fig. 4 Simplified lithostratigraphy of selected Mesozoic Karoo-aged successions of southern Gondwana (based on Barrett et al. 2020; Cahen 1983; Cahen and Lepersonne 1978; Catuneanu et al. 1998;

structures. The chronostratigraphic framework of the Upper Triassic to Lower Cretaceous basin development is poorly understood, as of a lack in datable marine fossils (Lovecchio et al. 2020). Following Frizon de Lamotte et al. (2015) and Lovecchio et al. (2020) a two-step scenario is possible: The first group of basins (Karoo I) comprises all NE-trending Carboniferous to Triassic depocenters (Aranos and Waterberg) may be related to subduction dynamics of the paleo-Pacific plate beneath SW Gondwana; and the second group (Karoo II) comprises the Jurassic to Lower Cretaceous depocenters may be related to the Karoo plume (Bouvet Hotspot). The tectonic evolution was accompanied by red bed sedimentation under extremely seasonal conditions (Fig. 2b, c), culminating under extremely arid conditions (Fig. 5; Miller 2008; Scheffler et al. 2006). Waterberg Basin sedimentation was capped by the occurrence of the c. $180 \mathrm{Ma}$ aged Lesotho hotspot volcanism (Moulin et al. 2011). After a c. $50 \mathrm{Ma}$ hiatus a vast paleoerg developed in the lower Cretaceous (e.g. Renne et al. 1996). Remnants of these Cretaceous eolian successions are reported from the Paraná (Brazil, Botucatu fm.) and Huab (Namibia, Twyfelfontein fm.) basins (Milner et al. 1994; Pinto et al. 2015), which themselves were overlain by flood basalts dated at c. $132 \mathrm{Ma}$ indicating an ongoing break-up of southern Gondwana (Lower Cretaceous; Fig. 2d; Renne et al. 1996). Sedimentary recycling continued during the Lower Cretaceous and a reworking of Lower Permian strata with Permo-Triassic ash-fall tuffs is suggested by sediments of the Brazilian Lower Cretaceous Botucatu fm. (Canile et al. 2016; Pinto et al. 2015).
Keyser 1973; Milani et al. 2007; Miller 2008; SACS 1980; Stanistreet and Stollhofen 1999). Formation names with an asterisk were sampled for this study

\section{Namibian Mesozoic successions}

The scarce occurrences of Namibian Mesozoic successions are mostly confined to the northern region of the country and can be found in the Huab, Waterberg and the northern Aranos basins (Figs. 1, 3).

The first occurrence of Mesozoic strata in Namibia is the so-called Neu Loore fm., which has been recognized within the uppermost part of the Aranos Basin, cropping out around the area of the town Leonardville (Fig. 3a). The formation is poorly known and consists of micaceous brownish-orange sandstones and red shales with a thickness ranging from c. 18 to c. $189 \mathrm{~m}$, which uncomfortably overlie the Rietmond shales of the Ecca Group (Miller 2008). The formation is characterized by abundant sudden facies changes (Miller 2008). A correlation with other Namibian successions is not possible but it might be associated with the Mosolotsane fm. of Botswana and the Molteno fm. of South Africa (Williamson 1996).

During the uppermost Triassic to Jurassic period, the NEtrending halfgraben of southern Africa emerged, leading to the deposition of the c. $700 \mathrm{~m}$ thick Waterberg Basin strata (Miller 2008), cropping out nowadays SE of the town Otjiwarongo (Fig. 3b). The successions can be subdivided into two formations: The lower Omingonde $\mathrm{fm}$. and the upper Etjo fm. (Fig. 4). The Omingonde fm. is comprised of reddish sandstones and shales cumulating a maximum thickness of $550 \mathrm{~m}$ (Fig. 5). Smith and Swart (2002) divide the formation into five sedimentary cycles: (1) paludal floodplains, (2) gravel-bed braided rivers, (3) loessic plains with saline lakes, (4) gravel-bed meandering rivers and (5) semi-arid 
Fig. 5 Schematic lithostratigraphic sections of the Aranos, Waterberg and Huab basins with selected outcrop photographs showing characteristic sedimentary features of Mesozoic successions of the respective basin. Columns are based on Horsthemke (1992), Stollhofen et al. (2000), Smith and Swart (2002), and Miller (2008). a, b Stratified eolian sandstones of the Cretaceous Twyfelfontein fm. (Huab Basin); c laminated brownish sandstones of the Upper Triassic Neu Loore fm. (Aranos Basin); d coarsegrained massive sandstones of the Jurassic Etjo fm. (Waterberg Basin); e layered sandstones of the Middle Triassic Omingonde fm. (Waterberg Basin)

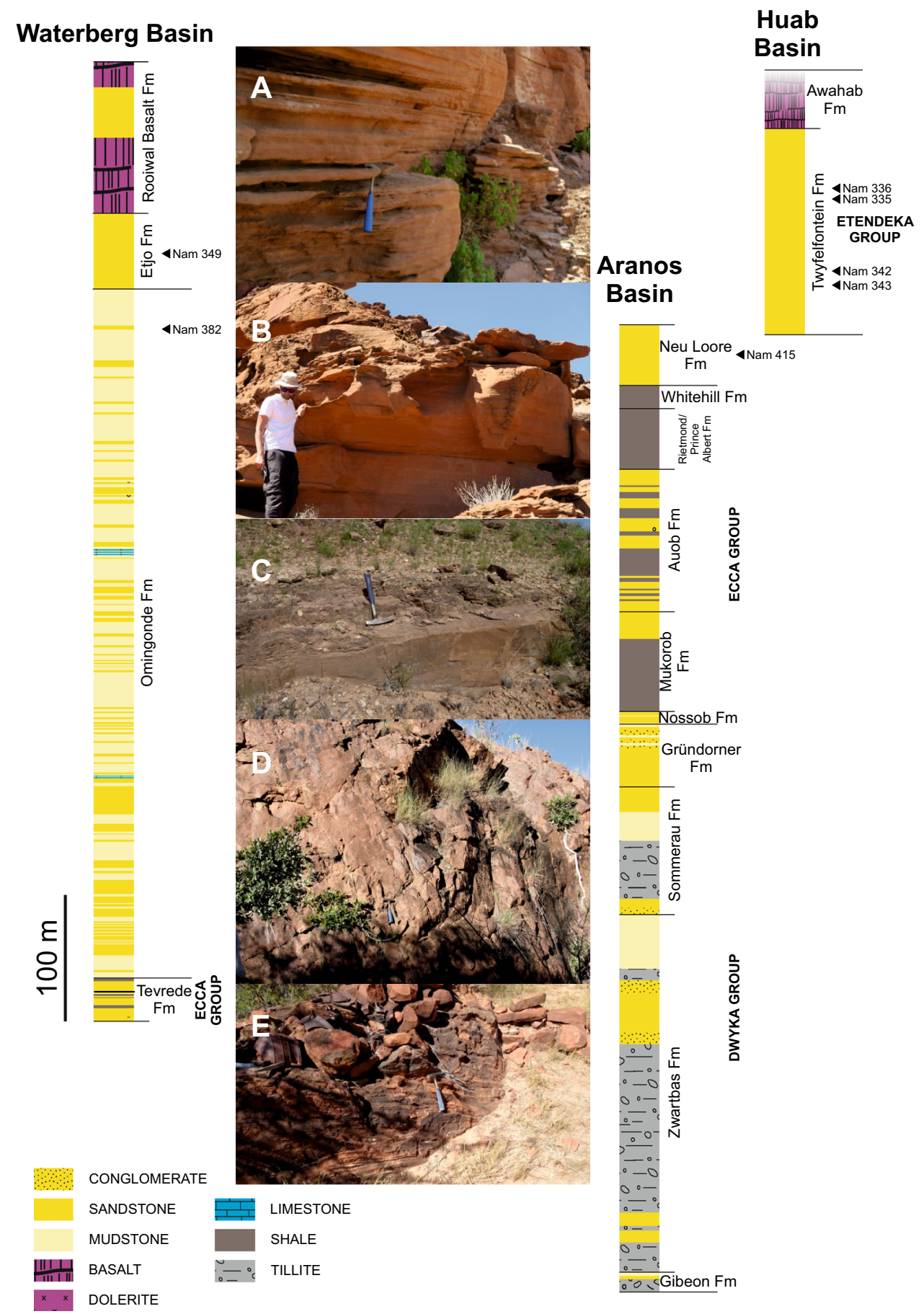

floodplains, which were deposited between c. 241 and c. $236 \mathrm{Ma}$ (Keyser 1973). It is important to notice that the successions show an increasing degree of aridity and high seasonality (Smith and Swart 2002). The overlying Etjo fm. consists of medium-grained pinkish to red eolian sandstones (Fig. 5), which have a maximum thickness of c. $150 \mathrm{~m}$ and can be divided into three units (Holzförster et al. 1999). The first unit is deposited under periodic sheet flood events during arid conditions (Holzförster et al. 1999). Deposition of the overlying second unit may represent a playa setting with eolian-sourced fluvial sediments, whereas the topmost unit consists of eolian fine to medium-grained cross-bedded sandstone deposits with flat-lying lenses hinting to heavy rainfall events (Miller 2008). The dip direction of the barchanoid cross-bedded successions is dominated by NE with minor occurrences of S (Bigarella 1973). As of the eolian character the Etjo fm. may be correlated with the Clarens fm. of the Main Karoo Basin (South Africa; Bowden 2013). 
The uppermost Mesozoic Namibian strata is represented by the c. $100 \mathrm{~m}$ thick Lower Cretaceous eolian Twyfelfontein fm. sandstones of the Huab Basin (Fig. 3), situated in the north-western part of the country (Fig. 3c). Because of its age the Twyfelfontein $\mathrm{fm}$. is not considered part of the Karoo Supergroup but was assigned to the overlying Etendeka Group (Milner et al. 1994). The base of the formation consists of fluvial interbeds, whereas the top is composed of light brown to reddish eolian sandstones (Fig. 5). The dominant dip direction of dune forests is NE to ENE with minor sets occurring from $N$ to SE (Horsthemke 1992). The imbrication of the basal fluvial beds suggests a deposition with westerly flowing currents (Miller 2008). At the top of the formation, the sandstones partly interfinger with or are covered by Lower Cretaceous flood basalts (Renne et al. 1996). The Twyfelfontein $\mathrm{fm}$. can be correlated with the Botucatu fm. of the Paraná Basin (Brazil), where W- to SW-directed wind patterns prevailed (Scherer and Goldberg 2007).

\section{Methods}

Samples were mainly collected in the northern part of Namibia along the roads C39, D2315, D3214, D2414 except sample Nam 415, which was collected east of Windhoek along road C20 (Fig. 3). All samples were representative for each facies found in the respective studied unit.

Zircon concentrates were separated from 1 to $3 \mathrm{~kg}$ whole rock material at the Senckenberg Naturhistorische Sammlungen Dresden (Museum für Mineralogie und Geologie). After crushing up the fresh sample in a jaw crusher, material was sieved for the fraction from 36 to $400 \mu \mathrm{m}$. Heavy mineral separation was achieved from the latter fraction using LST (lithium heteropolytungstate in water) prior to magnetic separation in a Frantz isomagnetic separator. Final selection of the zircon grains for $\mathrm{U}-\mathrm{Pb}$ dating was carried out by handpicking under a binocular microscope. When possible, at least 150 zircon grains of all grain sizes and morphological types were selected. After selection, the morphologic types according to Pupin (1980), length and width, roundness and surface structure were determined with a scanning electron microscope (e.g. Gärtner et al. 2018; and references therein). These characteristics of morphology are aimed to supplement the isotopic data and may help to improve the precision of provenance studies. Zircon size was determined using the software DIPS 2.9 (point electronic). Zircon grains were mounted in resin blocks and polished to half their thickness to expose their internal structure (e.g. oscillatory growth and older cores). Cathodoluminescence (CL)-imaging was performed using a SEM coupled to a HONOLD CL detector operating with a spot size of $550 \mathrm{~nm}$ at $20 \mathrm{kV}$.

The zircon grains were analysed for $\mathrm{U}, \mathrm{Th}$, and $\mathrm{Pb}$ isotopes by LA-SF ICP-MS techniques at the Museum für Mineralogie und Geologie (GeoPlasma Lab, Senckenberg Naturhistorische Sammlungen Dresden), using a Thermo-Scientific Element 2 XR sector field ICP-MS (single-collector) coupled to an asi RESOlution $193 \mathrm{~nm}$ excimer laser. Each analysis consisted of $15 \mathrm{~s}$ background acquisition followed by $30 \mathrm{~s}$ data acquisition, using a laser spot-size of $25 \mu \mathrm{m}$ and were bracketed by zircon reference material measurements. A common- $\mathrm{Pb}$ correction based on the interference- and background-corrected ${ }^{204} \mathrm{~Pb}$ signal and a model $\mathrm{Pb}$ composition (Stacey and Kramers 1975) was carried out if necessary. The necessity of the correction is judged on whether the corrected $207 \mathrm{~Pb} / 206 \mathrm{~Pb}$ lies outside of the internal errors of the measured ratios (Frei and Gerdes 2009). Discordant analyses were generally interpreted with care. Raw data were corrected for background signal, common $\mathrm{Pb}$, laser-induced elemental fractionation, instrumental mass discrimination, and time-dependant elemental fractionation of $\mathrm{Pb} / \mathrm{Th}$ and $\mathrm{Pb} / \mathrm{U}$ using an Excel ${ }^{\circledR}$ spreadsheet program developed by Axel Gerdes (Institute of Geosciences, Johann Wolfgang Goethe-University Frankfurt, Frankfurt am Main, Germany). Reported uncertainties were propagated by quadratic addition of the external reproducibility obtained from the reference zircon GJ-1 ( 0.6\% and $0.5-1 \%$ for the ${ }^{207} \mathrm{~Pb} /{ }^{206} \mathrm{~Pb}$ and ${ }^{206} \mathrm{~Pb} /{ }^{238} \mathrm{U}$, respectively) during individual analytical sessions and within-run precision of each analysis. To test the accuracy of the measurements and data reduction, we included the Plešovice zircon as a secondary reference in our analyses and which gave reproducibly ages of c. $337 \mathrm{Ma}$, fitting with the results of Sláma et al. (2008). Nonmetric Multi-dimensional scaling (MDS) plots based on the Kolmogorov-Smirnov statistical analysis (Vermeesch 2013) were produced using the provenance package for the statistic program $R$ 3.6.1 (Vermeesch et al. 2016). MDS produces a point configuration in which similar samples plot close together and dissimilar samples plot far apart To compare the sample zircon age data with zircon age data from published studies from southern African structural units (along time) and from other Mesozoic Karoo-aged successions (geographically). Kernel density estimation plots were produced using the detzrcr package for the statistic program $R$ 3.6.1 by Andersen et al. (2018b). The ${ }^{207} \mathrm{~Pb} /{ }^{206} \mathrm{~Pb}$ age was taken for interpretation for all zircon grains $>1.5 \mathrm{Ga}$, and the ${ }^{206} \mathrm{~Pb} /{ }^{238} \mathrm{U}$ ages for younger grains as recommended by Puetz (2018). For further details on analytical protocol and data processing see Gerdes and Zeh (2006). A U-Pb analysis is concordant when it overlaps within uncertainty with the concordia. So, it seems to be appropriate to exclude results with a low level of concordance $\left({ }^{206} \mathrm{~Pb} /{ }^{238} \mathrm{U}\right.$ age $/{ }^{207} \mathrm{~Pb} /{ }^{206} \mathrm{~Pb}$ age $\left.\times 100\right)$, but very large errors that overlap with the concordia from interpretation. Thus, an interpretation with respect to the obtained ages was done for all grains within the concordance interval 
of $90-110 \%\left({ }^{206} \mathrm{~Pb} /{ }^{238} \mathrm{U}\right.$ age $/{ }^{207} \mathrm{~Pb} /{ }^{206} \mathrm{~Pb}$ age $\left.\times 100\right)$ which is often used (Spencer et al. 2016). To exclude lead loss effects, analyses with $>2.5 \%$ corrected common lead were rejected by default and were not considered for further interpretation (Andersen et al. 2019a). $\mathrm{U}$ and $\mathrm{Pb}$ content and $\mathrm{Th} / \mathrm{U}$ ratio were calculated relative to the GJ-1 zircon reference and are accurate to approximately $10 \%$. Analytical results of $\mathrm{U}-\mathrm{Th}-\mathrm{Pb}$ isotopes and calculated $\mathrm{U}-\mathrm{Pb}$ ages are given in the supplementary data. The stratigraphic time scale of Gradstein et al. (2012) was used.

Hafnium isotope measurements were carried out using a Thermo-Finnigan NEPTUNE multi-collector ICP-MS at the Institute of Geosciences, Johann Wolfgang GoetheUniversity Frankfurt, Frankfurt am Main, Germany coupled to RESOlution M50 $193 \mathrm{~nm}$ ArF Excimer (Resonetics) laser system following the method described in Gerdes and Zeh $(2006,2009)$. Spots of $40 \mu \mathrm{m}$ in diameter were drilled with a repetition rate of $4.5-5.5 \mathrm{~Hz}$ and an energy density of $6 \mathrm{~J} / \mathrm{cm}^{2}$ during $50 \mathrm{~s}$ of data acquisition. The instrumental mass bias for $\mathrm{Hf}$ isotopes was corrected using an exponential law and a ${ }^{179} \mathrm{Hf} /{ }^{177} \mathrm{Hf}$ value of 0.7325 . In the case of $\mathrm{Yb}$ isotopes, the mass bias was corrected using the $\mathrm{Hf}$ mass bias of the individual integration step multiplied by a daily $\beta \mathrm{Hf} / \beta \mathrm{Yb}$ offset factor (Gerdes and Zeh 2009). All data were adjusted relative to the JMC475 of ${ }^{176} \mathrm{Hf} /{ }^{177} \mathrm{Hf}$ ratio $=0.282160$ and quoted uncertainties are quadratic additions of the within-run precision of each analysis and the reproducibility of the JMC475 $(2 \mathrm{SD}=0.0028 \%, n=8)$. Accuracy and external reproducibility of the method was verified by repeated analyses of reference zircon GJ-1 and Plešovice, which yielded a ${ }^{176} \mathrm{Hf} /{ }^{177} \mathrm{Hf}$ of $0.282007 \pm 0.000026(2 \mathrm{SD}, n=42)$ and $0.0282469 \pm 0.000023(n=20)$, respectively. This is in agreement with previously published results (e.g. Gerdes and Zeh 2006; Sláma et al. 2008) and with the LA-MCICP-MS long-term average of GJ-1 (0.282010 \pm 0.000025 ; $n>800)$ and Plešovice $(0.282483 \pm 0.000025, n>300)$ reference zircon at the Frankfurt lab.

The initial ${ }^{176} \mathrm{Hf} /{ }^{177} \mathrm{Hf}$ values are expressed as ${ }_{\varepsilon} \mathrm{Hf}_{(\mathrm{t})}$, which is calculated using a decay constant value of $1.867 \times 10-11$ year-1, CHUR after Bouvier et al. (2008; ${ }^{176} \mathrm{Hf} /{ }^{177} \mathrm{Hf}_{\mathrm{CHUR}}$, today $=0.282785$ and ${ }^{176} \mathrm{Lu} /{ }^{177} \mathrm{Hf}_{\mathrm{CHUR}}$, today $=0.0336$ ) and the apparent $\mathrm{U}-\mathrm{Pb}$ ages obtained for the respective domains are shown in the supplementary data A. For the calculation of Hf two-stage model ages (TDM) in billion years, the measured ${ }^{176} \mathrm{Lu} /{ }^{177} \mathrm{Lu}$ of each spot (first stage $=$ age of zircon), a value of 0.0113 for the average continental crust, and a juvenile crust ${ }^{176} \mathrm{Lu} /{ }^{177} \mathrm{LuNC}=0.0384$ and ${ }^{176} \mathrm{Hf} /{ }^{177} \mathrm{Hf} \mathrm{NC}=0.283165$ (average MORB; Chauvel et al. 2007) were used.

The geochemical analyses of the rock samples were carried out by FUS-ICP and FUS-MS by Actlabs in Ancaster (Ontario, Canada).

\section{Results}

For this study, we analysed zircon grains from seven Mesozoic sandstone samples. In total 1046 zircon grains were investigated with respect to their morphological features (Fig. 6), including width, length and roundness after Gärtner et al. (2013) and morphotypes after Pupin (1980) (Fig. 7). On these zircon grains $1079 \mathrm{U}-\mathrm{Th}-\mathrm{Pb}$ and $187 \mathrm{La}-\mathrm{Hf} \mathrm{LA}-\mathrm{ICP}-\mathrm{MS}$ analyses on selected regions were performed (Figs. 8, 9a). Of all U-Th-Pb analyses, 690 yielded a near concordance between 90 and $110 \%$. In general, all investigated samples of Namibian Mesozoic sandstones yield a major Pan-African c. 0.5-0.7 Ga (Neoproterozoic to early Cambrian) age peak, and a minor peak at 1.8-2.1 Ga (late Rhyacian to Orosirian). Archean ages are scarce but could be observed in each investigated sample. Besides sample Nam 415, all samples show comparable age spectra featuring Lower Triassic to Permian zircon ages.

Geochemical data obtained for all samples but Nam 336 and 342 is useful to determine recycling, weathering, and average composition of source areas. Chondritic normalised REE diagrams of samples Nam 415 and Nam 382 show a negative Eu-anomaly typical for reduced conditions (Fig. 10a). The discriminant function diagram after Roser and Korsch (1986) of the sediments provide insights about their source rock composition. Four samples fall into the field of quartzose sedimentary provenance and sample Nam 415 plot into the field of intermediate igneous provenance (Fig. 10b). On the La/Th vs Hf diagram a mix between upper continental crust and lower continental crust provenance composition for the investigated samples of this study is given by $\mathrm{La} / \mathrm{Th}$ ratios between 3.33 and 4.80 showing no sedimentary recycling trend (Fig. 10c), also confirmed by the $\mathrm{Th} / \mathrm{U}$ vs Th plot indicating only a weak weathering trend (Fig. 10d).

An overview of the most important results of this study may be found in Table 1. All obtained $\mathrm{U}-\mathrm{Th}-\mathrm{Pb}$ and La-Hf LA-ICP-MS measurements including morphological features of each grain can be found in the supplementary data.

In the following, we give a more detailed sample description, sorted after the respective basin and after that from bottom to the top of the successions.

\section{Nam 335 and Nam 336, S20 26' 50.3", E14 $32^{\prime}$ 34.0", sandstone, Lower Cretaceous, Etendeka Group, Twyfelfontein Formation}

The brownish (Nam 335) and whitish (Nam 336) sandstones were collected along road C39 about $45 \mathrm{~km} \mathrm{~W}$ of 

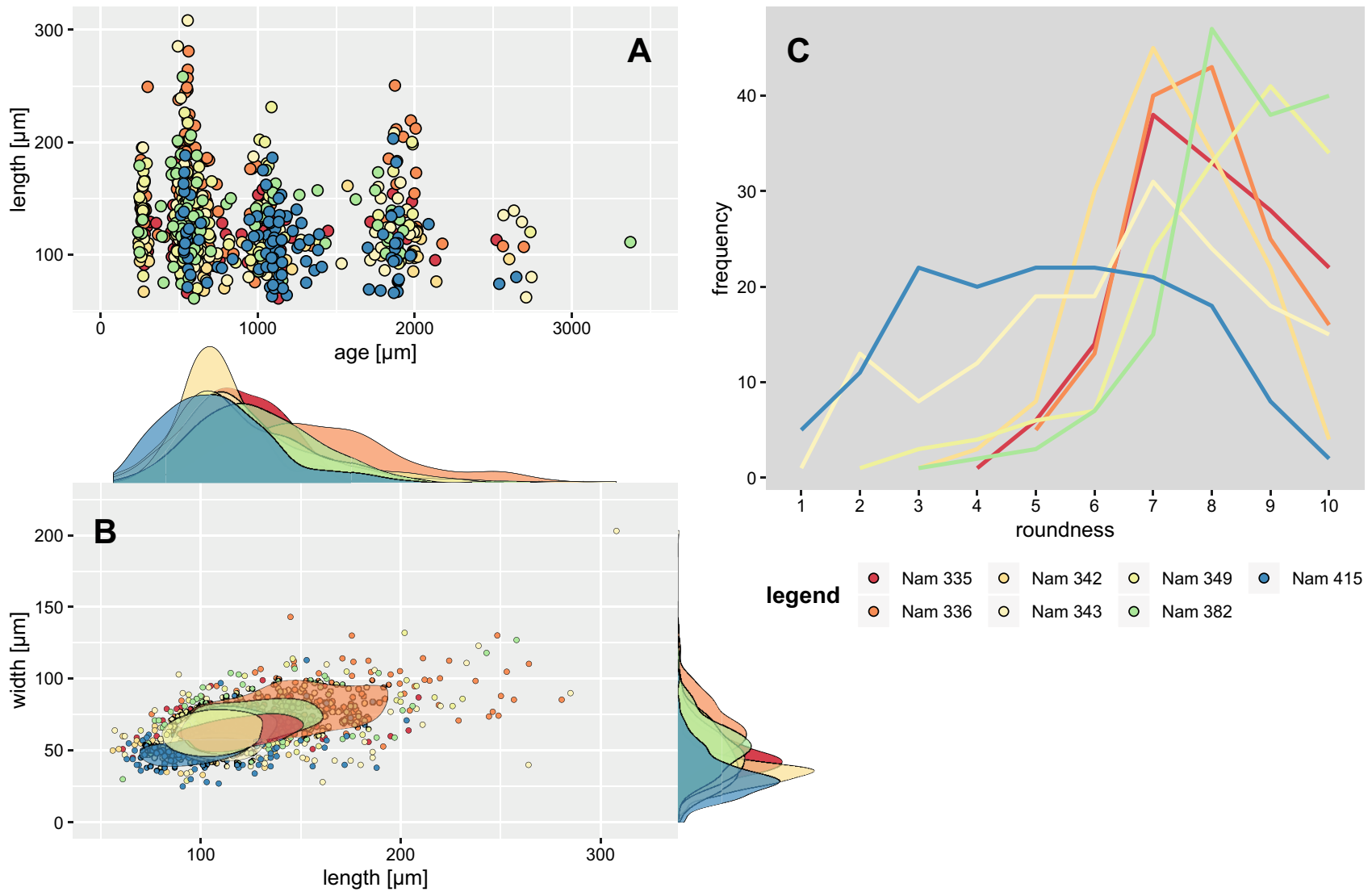

Fig. 6 Distribution and mean values of roundness classes of the investigated zircon grains of each sample. a Length vs age plot of each investigated detrital zircon grain of this study. $\mathbf{b}$ Length vs width plot of each investigated detrital zircon grain including kernel density

estimations of all analyses revealing length vs age distribution patterns. Furthermore, density probability plots are given for length and width values for each sample. $\mathbf{c}$ Roundness value distribution of each sample investigated in this study
Fig. 7 Abundance of zircon morphotype shape classification following Pupin (1980) of the investigated samples

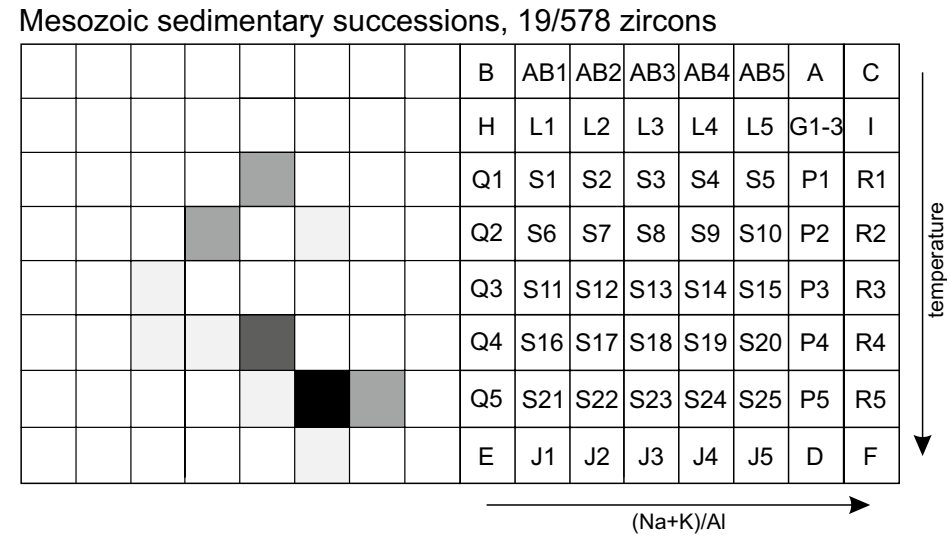

most abundant morphotypes of this study

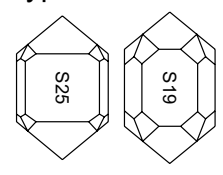

the city of Khorixas. The sampled section lies directly below a Jurassic dolerite intrusion and consists of two distinct layers, interpreted as single dune sets. Both layers feature foreset pinstriping with massive, interbedded avalanche layers of variable thickness and grading. The grains of the sandstones are usually well rounded and well sorted and range from fine to coarse. Of $157 \mathrm{U}-\mathrm{Th}-\mathrm{Pb}$ isotopic analyses of Nam 335, 113 yield ages between $240 \pm 6$ and $2778 \pm 22 \mathrm{Ma}$ and of 146 analyses of sample Nam 336, 104 near concordant analyses yield ages between $252 \pm 4$ and $2561 \pm 11 \mathrm{Ma}$, resulting in one main age group for both samples ranging from 450 to $700 \mathrm{Ma}$ (58\% of all near concordant analyses), with peaks at 500 and $550 \mathrm{Ma}$ (Fig. 8). Minor age groups cluster in the range from 240 
Fig. 8 Obtained detrital zircon $\mathrm{U}-\mathrm{Pb}$ ages presented in this study for each sample in percentage 'pie charts'. Pie chart colours correspond with phases of extensive crustal growth. Also kernel density estimate age distribution curves (bandwidth: $15 \mathrm{Ma}$ ) for each sample are shown, where $n=$ number of concordant zircon $\mathrm{U}-\mathrm{Pb}$ measurements/total number of measurements for the respective sample

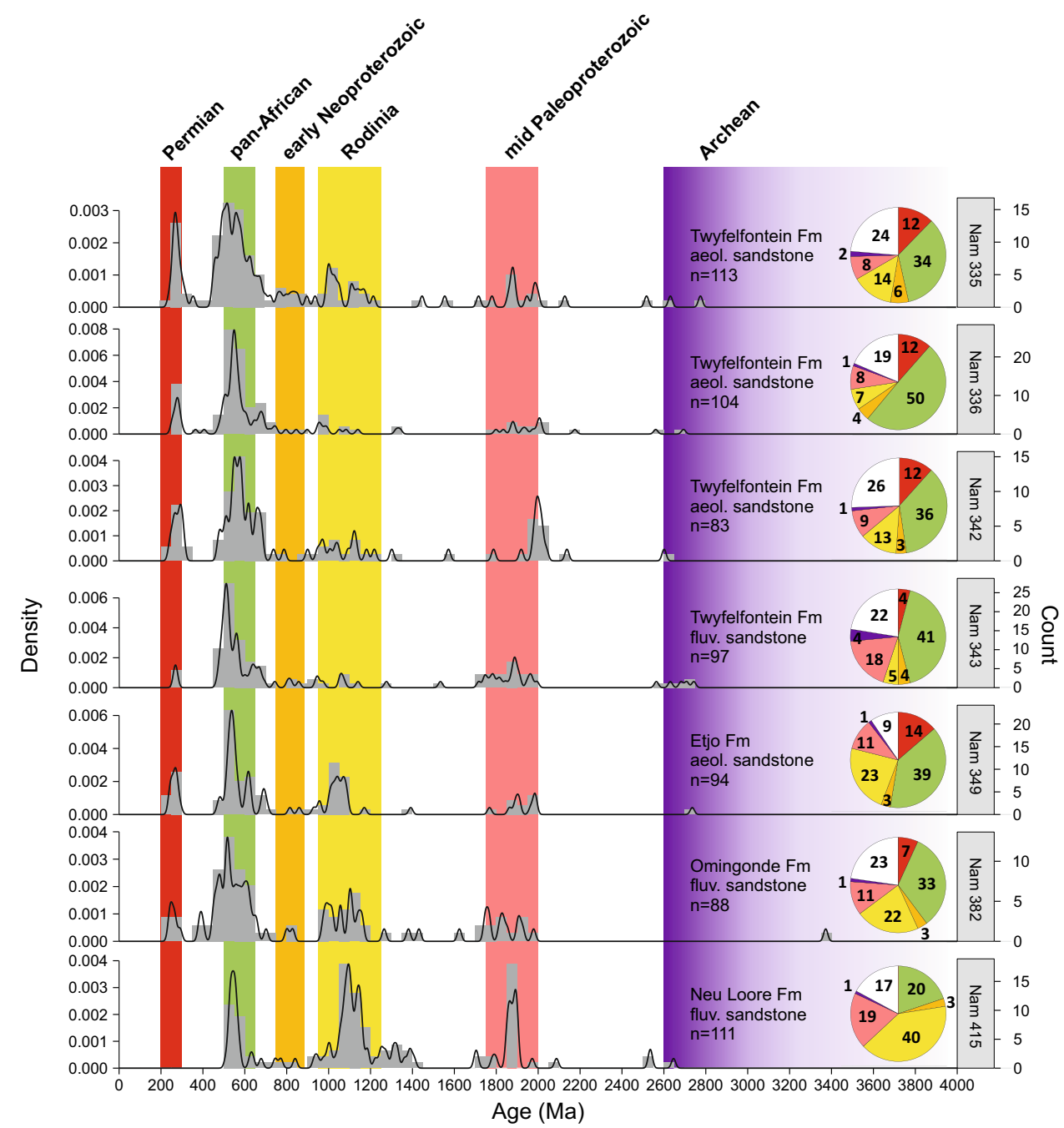

Age (Ma) to $300 \mathrm{Ma}$ and from 1750 to $2000 \mathrm{Ma}$ (12 and 7\%, respectively; Fig. 8). ${ }_{\varepsilon} \mathrm{Hf}_{(\mathrm{t})}$ values range from -38.9 to 16.9 resulting in $\mathrm{T}_{\mathrm{DM}}$ ages between 1.07 and $2.64 \mathrm{Ga}$ (Fig. 9a).

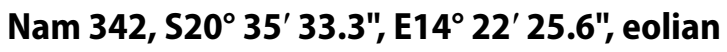 sandstone, Lower Cretaceous, Etendeka Group, Twyfelfontein Formation}

The brown eolian sandstone was collected at the type locality Twyfelfontein along road D3214 (Fig. 3). Similar to samples Nam 335 and Nam 336, the fine to coarse-grained sandstones show pinstriping and can be divided into individual cross-bedded units of several metres thickness, which are interpreted as single dune sets. The $153 \mathrm{U}-\mathrm{Th}-\mathrm{Pb}$ zircon analyses gave 83 concordant ages, ranging from $242 \pm 5$ to $2601 \pm 24 \mathrm{Ma}$. One main age group appears from 450 to $700 \mathrm{Ma}$ and further peaks are at 500 and $575 \mathrm{Ma}(47 \%$ of all near concordant analyses; Fig. 8). Minor age groups appear from 240 to $300 \mathrm{Ma}$ and from 1900 to $2050 \mathrm{Ma}$ (12\% of all near concordant analyses each; Fig. 8).

\section{Nam 343, S20 35' 33.0", E14 $22^{\circ} 2$ 4.8", eolian sandstone, Lower Cretaceous, Etendeka Group, Twyfelfontein Formation}

The brown well-bedded eolian sandstone contained several $\mathrm{cm}$-sized subrounded quartz pebbles and was collected at the type locality Twyfelfontein along road D3214 (Fig. 3) in the lower part of the section of sample Nam 342, representing the base of the Twyfelfontein $\mathrm{fm}$. In contrast, to sample Nam 342, the sandstones are reddish, well-bedded, immature, and show no pinstriping. The $160 \mathrm{U}-\mathrm{Th}-\mathrm{Pb}$ analyses gave 97 concordant ages, ranging from $265 \pm 4$ to $2743 \pm 15 \mathrm{Ma}$. One prominent main age group ranging from 470 to $700 \mathrm{Ma}$ (56\% of all near concordant analyses) could be observed (Fig. 8). One minor age group appears from 1700 to $2000 \mathrm{Ma}$ (22\% of all concordant analyses; Fig. 8). 

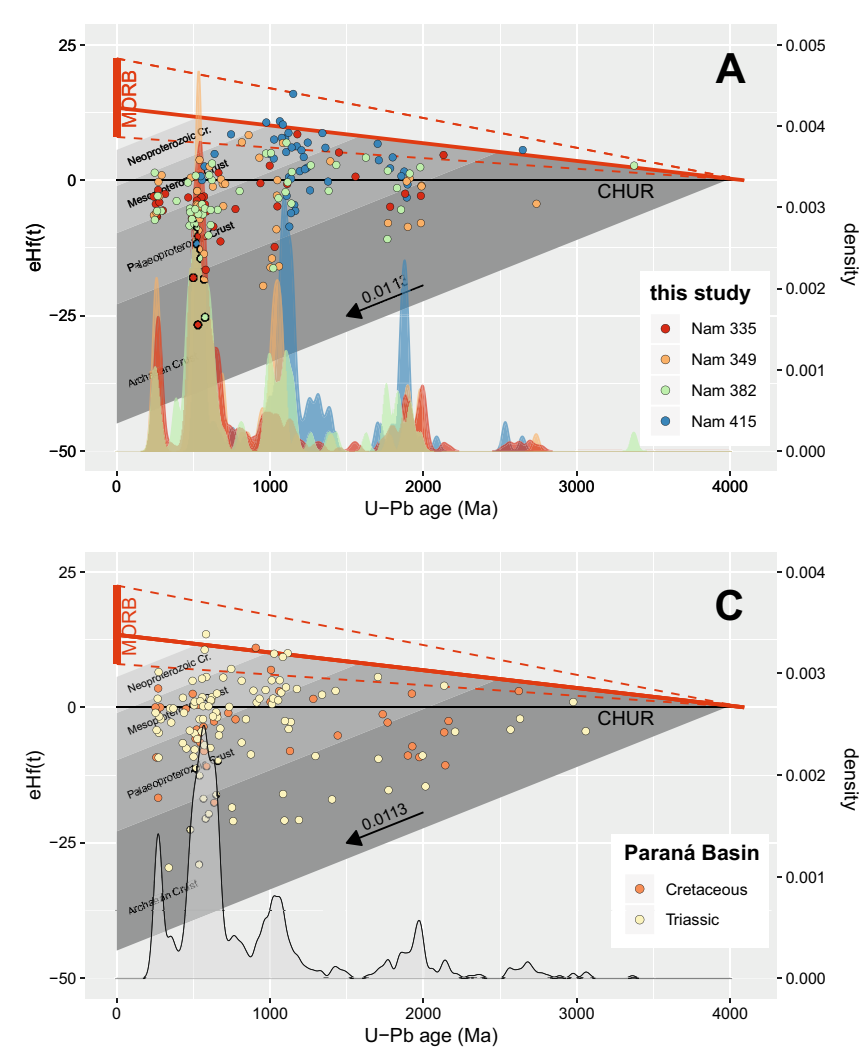

Fig. $9{ }_{\varepsilon} \mathrm{Hf}_{(\mathrm{t})}$ versus age diagrams of zircon grains of southern Gondwanan Mesozoic successions and kernel density estimations of all analyses. a ${ }_{\varepsilon} \mathrm{Hf}_{(\mathrm{t})}$ versus age data obtained for this study and kernel density estimations for the investigated samples. b Published ${ }_{\varepsilon} \mathrm{HF}_{(\mathrm{t})}$

\section{Nam 349, S21 ${ }^{\circ} 04^{\prime} 05.7^{\prime \prime}, \mathrm{E}^{\circ} 6^{\circ} 24^{\prime}$ 04.4", eolian sandstone, Lower Jurassic, Etjo Formation}

Sample Nam 349 is a bedded, yellowish to brownish fineto medium-grained eolian sandstone, and was collected at a section c $115 \mathrm{~km} \mathrm{NNW}$ of the town Okahandja, near the road D2414 at farm Etjo Nord 93 (Fig. 3). The section consisted of c. $95 \%$ cross-bedded sandstone facies, intercalated with minor laminated mudstone facies, which is interpreted as interdune flooding, and a coarse-grained sand and pebble lag facies. The well-sorted sandstones of the unit are mica free and texturally mature. Locally slumping does occur. The 153 performed $\mathrm{U}-\mathrm{Th}-\mathrm{Pb}$ analyses 94 gave near concordant ages, ranging from $242 \pm 7$ to $2736 \pm 30 \mathrm{Ma}$. One main age group ranges from 500 to $700 \mathrm{Ma}$, featuring $44 \%$ of all near concordant analyses, whereas considerable minor age groups ranging from 240 to $300 \mathrm{Ma}(14 \%)$, from 1000 to $1200 \mathrm{Ma}(20 \%)$, and from 1750 to $2000 \mathrm{Ma}$ (11\%; Fig. 8). Of $50 \mathrm{La}-\mathrm{Hf}$ isotopic analyses ${ }_{\varepsilon} \mathrm{Hf}_{(\mathrm{t})}$ values ranging from -19.5 to 8.4 resulting in $\mathrm{T}_{\mathrm{DM}}$ ages from 0.94 to $3.23 \mathrm{Ga}$ (Fig. 9).
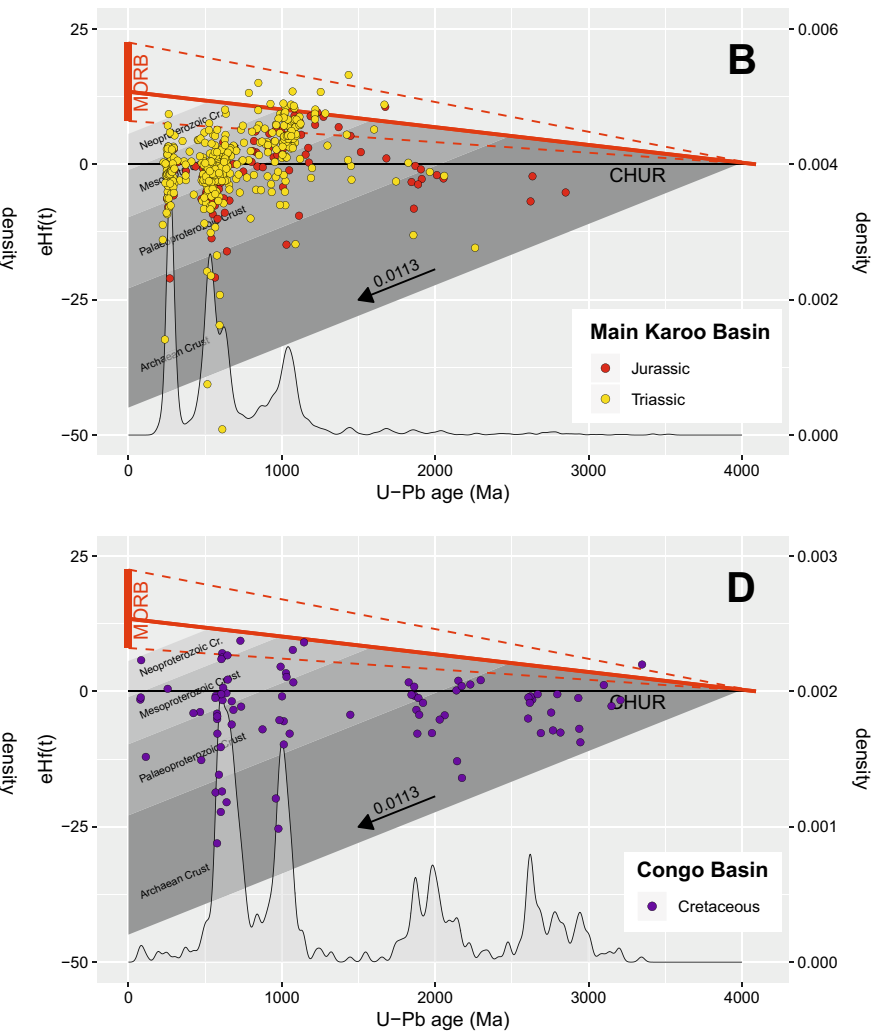

versus age data of the Main Karoo Basins (Andersen et al. 2016b). c Published ${ }_{\varepsilon} \mathrm{HF}_{(\mathrm{t})}$ versus age data of the Paraná Basin (Griffis et al. 2018). d Published ${ }_{\varepsilon} \mathrm{Hf}_{(\mathrm{t})}$ versus age data of the Congo Basin (Owusu Agyemang et al. 2016)

\section{Nam 382, S20 $28^{\prime} 26.5^{\prime \prime}, \mathrm{E}^{\circ}{ }^{\circ} 18^{\prime} 25.1^{\prime \prime}$, fluvial sandstone, mid-Triassic, Omingonde Formation}

A brownish sandstone was collected c. $86 \mathrm{~km}$ east of the town Otjiwarongo, near road D2512 below the Waterberg plateau (Fig. 3). The section consisted of cross-bedded in-channel accumulations of sandstones with scattered pebbles of mudstones. The sandstones were intercalated with aqueous siltstones, including thin, elongate lenses of reworked pedogenic carbonate nodules. The $152 \mathrm{U}-\mathrm{Th}-\mathrm{Pb}$ analyses gave 88 near concordant ages between $240 \pm 4$ and $3372 \pm 13 \mathrm{Ma}$. One major age group ranges from 450 to $660 \mathrm{Ma}$ (44\%), with peaks at 510 and $600 \mathrm{Ma}$ (Fig. 7). Minor age group occur from 240 to $300 \mathrm{Ma}(6 \%)$, from 950 to $1150 \mathrm{Ma}$ (22\%), and from 1750 to $2000 \mathrm{Ma}(11 \%$; Fig. 8). Obtained ${ }_{\varepsilon} \mathrm{Hf}_{(\mathrm{t})}$ values of $49 \mathrm{La}-\mathrm{Hf}$ isotopic analyses range from -25.5 to 7.4 resulting in $\mathrm{T}_{\mathrm{DM}}$ ages between 0.87 and $3.36 \mathrm{Ga}$ (Fig. 9a). 

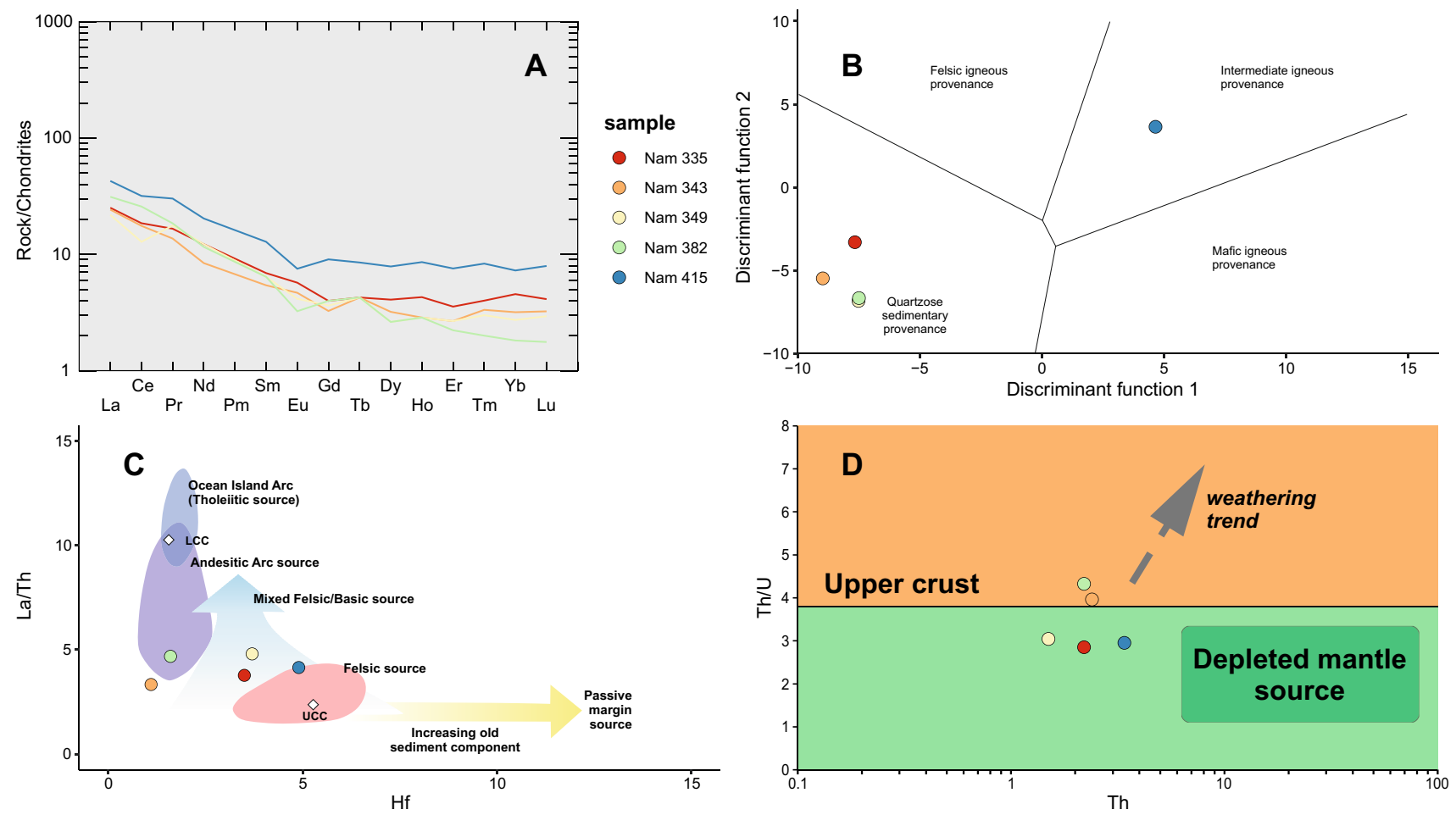

Fig. 10 Plots of geochemical data of investigated Mesozoic sedimentary samples from the Huab and Waterberg basins and from the Neu Loore outcrops. a Chondrite-normalized REE patterns of measured values (after Nakamura 1974). b Discriminant function diagram after Roser and Korsch (1986) for the provenance of all investigated samples in this study. Fields for dominantly mafic, intermediate and felsic igneous provenances are shown as well as the field for a quartzose

\section{Nam 415, S23 13' 31.0", E18 $42^{\prime} 03.1$ ", fluvial sandstone, mid to late Triassic, Neu Loore Formation}

The stratified mica-rich brownish sandstone was sampled along road C20, about $30 \mathrm{~km}$ north of the town Leonardville. The sampled section was made up coarse to medium-grained sandstones, interbedded with very fine-grained, highly micaceous sandstone or siltstone, featuring trough cross-bedding, pointings towards several rapid facies changes. Of all 158 $\mathrm{U}-\mathrm{Th}-\mathrm{Pb}$ analyses, 111 gave concordant ages, ranging from $511 \pm 10$ to $2646 \pm 10 \mathrm{Ma}$. Three major age group occur between 500 and $700 \mathrm{Ma}$ peaking at $540 \mathrm{Ma}$ (21\% of all near concordant analyses), from 1000 to 1250 Ma peaking at 1080 and $1140 \mathrm{Ma}(41 \%)$, and from 1700 to 2000 Ma peaking at $1880 \mathrm{Ma}$ (21\%; Fig. 8). Obtained ${ }_{\varepsilon} \mathrm{Hf}_{(\mathrm{t})}$ values of $49 \mathrm{La}-\mathrm{Hf}$ isotopic analyses range from -11.8 to 16.0 resulting in $\mathrm{T}_{\mathrm{DM}}$ ages between 0.83 and $2.61 \mathrm{Ga}$ (Fig. 9a). sedimentary provenance. c $\mathrm{La} / \mathrm{Th}$ vs. Hf diagram after Floyd and Leveridge (1987) and $\mathrm{Gu}$ et al. (2002) to determine average source composition for the investigated sediments. LCC lower continental crust, $U C C$ upper continental crust. d Th/U vs Th diagram after McLennan et al. (1993). All diagrams are based on data given in supplementary material

\section{Discussion}

\section{Protosources of the sediments}

All investigated samples show Upper Neoproterozoic, Mesoproterozoic and Paleoproterozoic detrital zircon age peaks and minor amounts of Archean as well as Upper Tonian (c. $0.75-0.85 \mathrm{Ga}$ ) ages (Fig. 8). The oldest prominent age peak is confined to the Mid-Paleoproterozoic (Orosirian; Fig. 8). Zircon ages of $1.9 \mathrm{Ga}$ can be assigned to the Richtersveld Magmatic Arc, which is part of the Namaqua Sector (Hofmann et al. 2014; Macey et al. 2017). In addition, the Orange River Group (also part of the Namaqua Sector) can also provide zircon grains of that age, as these strata feature zircon ages ranging from 1.8 to 2.1 Ga (Minnaar 2011; Pettersson et al. 2007; Van Niekerk 2006). Late Neoproterozoic to Mesoproterozoic (late Tonian to Stenian) ages are present 
Table 1 Summary of the most important results of the detrital zircon analysis

\begin{tabular}{|c|c|c|c|c|c|c|c|c|c|}
\hline & Coordinates & Formation & Lithology & $\begin{array}{l}\text { Number of } \\
\text { grains (total, } \\
\text { U-Th-Pb } \\
\text { analyses, } \\
90-110 \% \\
\text { conc }\end{array}$ & $\begin{array}{l}\text { Minimum, } \\
\text { maximum } \\
\text { and mean } \\
\text { length }(\mu \mathrm{m})\end{array}$ & $\begin{array}{l}\text { Minimum, } \\
\text { maximum } \\
\text { and mean } \\
\text { width }(\mu \mathrm{m})\end{array}$ & $\begin{array}{l}\text { Mean } \\
\text { roundness } \\
\text { (classes 1-10 } \\
\text { according to } \\
\text { Gärtner et al. } \\
2013 \text { ) }\end{array}$ & $\begin{array}{l}\text { Youngest } \\
\text { detrital grain } \\
\text { (90-110\% } \\
\text { conc.) (Ma) }\end{array}$ & $\begin{array}{l}\text { Oldest } \\
\text { detrital grain } \\
(90-110 \% \\
\text { conc.) }(\mathrm{Ma})\end{array}$ \\
\hline Nam 335 & $\begin{array}{l}\mathrm{S} 20^{\circ} 26^{\prime} \\
50.3^{\prime \prime}, \mathrm{E} 14^{\circ} \\
32^{\prime} 34.0^{\prime \prime}\end{array}$ & $\begin{array}{l}\text { Twyfelfon- } \\
\text { tein }\end{array}$ & Sandstone & $\begin{array}{l}142 \\
157 \\
113\end{array}$ & $\begin{array}{l}61 \\
209 \\
120.19\end{array}$ & $\begin{array}{l}41 \\
99 \\
64.72\end{array}$ & 7.89 & $240 \pm 6$ & $2778 \pm 22$ \\
\hline Nam 336 & $\begin{array}{l}\mathrm{S} 20^{\circ} 26^{\prime} \\
50.3^{\prime \prime}, \mathrm{E} 14^{\circ} \\
32^{\prime} 34.0^{\prime \prime}\end{array}$ & $\begin{array}{l}\text { Twyfelfon- } \\
\text { tein }\end{array}$ & Sandstone & $\begin{array}{l}142 \\
146 \\
104\end{array}$ & $\begin{array}{l}76 \\
281 \\
159.06\end{array}$ & $\begin{array}{l}53 \\
143 \\
83.13\end{array}$ & 7.83 & $252 \pm 4$ & $2561 \pm 11$ \\
\hline Nam 342 & $\begin{array}{l}\mathrm{S} 20^{\circ} 35^{\prime} \\
33.3^{\prime \prime}, \mathrm{E} 14^{\circ} \\
22^{\prime} 25.6^{\prime \prime}\end{array}$ & $\begin{array}{l}\text { Twyfelfon- } \\
\text { tein }\end{array}$ & Sandstone & $\begin{array}{l}147 \\
153 \\
83\end{array}$ & $\begin{array}{l}56 \\
182 \\
107.69\end{array}$ & $\begin{array}{l}33 \\
84 \\
55.18\end{array}$ & 7.21 & $242 \pm 5$ & $2601 \pm 24$ \\
\hline Nam 343 & $\begin{array}{l}\mathrm{S} 20^{\circ} 35^{\prime} \\
33.0^{\prime \prime}, \mathrm{E} 14^{\circ} \\
22^{\prime} 24.8^{\prime \prime}\end{array}$ & $\begin{array}{l}\text { Twyfelfon- } \\
\text { tein }\end{array}$ & Sandstone & $\begin{array}{l}160 \\
160 \\
97\end{array}$ & $\begin{array}{l}57 \\
308 \\
124.94\end{array}$ & $\begin{array}{l}28 \\
203 \\
65.23\end{array}$ & 6.43 & $265 \pm 4$ & $2743 \pm 15$ \\
\hline Nam 349 & $\begin{array}{l}\mathrm{S} 21^{\circ} 04^{\prime} \\
05.7^{\prime \prime}, \mathrm{E} 16^{\circ} \\
24^{\prime} 04.4^{\prime \prime}\end{array}$ & Etjo & Sandstone & $\begin{array}{l}153 \\
153 \\
94\end{array}$ & $\begin{array}{l}70 \\
231 \\
124.27\end{array}$ & $\begin{array}{l}29 \\
132 \\
68.87\end{array}$ & 8.10 & $242 \pm 7$ & $2736 \pm 30$ \\
\hline Nam 382 & $\begin{array}{l}\mathrm{S} 20^{\circ} 28^{\prime} \\
26.5^{\prime \prime}, \mathrm{E} 17^{\circ} \\
18^{\prime} 25.1^{\prime \prime}\end{array}$ & Omingonde & Sandstone & $\begin{array}{l}151 \\
152 \\
88\end{array}$ & $\begin{array}{l}61 \\
258 \\
129.54\end{array}$ & $\begin{array}{l}30 \\
127 \\
71.66\end{array}$ & 8.50 & $240 \pm 4$ & $3372 \pm 13$ \\
\hline Nam 415 & $\begin{array}{l}{\mathrm{S} 23^{\circ} 13^{\prime}} \\
31.0^{\prime \prime}, \mathrm{E} 18^{\circ} \\
42^{\prime} 03.1^{\prime \prime}\end{array}$ & Neu Loore & Sandstone & $\begin{array}{l}151 \\
158 \\
111\end{array}$ & $\begin{array}{l}63 \\
203 \\
108.93\end{array}$ & $\begin{array}{l}25 \\
113 \\
53.45\end{array}$ & 5.28 & $511 \pm 10$ & $2646 \pm 10$ \\
\hline
\end{tabular}

in all investigated samples but seem to thin out going upward in stratigraphy (Fig. 8). Possible basement sources are the Mesoproterozoic Namaqua-Natal Sector (e.g. Clifford et al. 2004; Macey et al. 2018; Raith et al. 2003) as well as the Irumide Belt (e.g. De Waele et al. 2009). The third and most prominent zircon age peak featured by all analysed samples is of Neoproterozoic to Cambrian age. These ages can be derived from denudated pan-African mountain ranges of today's Damara, Kaoko, Saldania and Copperbelt (e.g. Foster et al. 2015; Frimmel et al. 2013; Gray et al. 2008; Konopásek et al. 2017; Konopásek et al. 2008; Sanz 2005). Detrital pan-African zircon ages are also prominent within other investigated Karoo-aged successions throughout SW Gondwana (e.g. Canile et al. 2016; Griffis et al. 2018; Linol et al. 2016; Viglietti et al. 2018). As remnants of the panAfrican orogeny are found all over the Gondwana supercontinent (Kennedy 1964), it is not surprising to find evidence of this major orogenic event in younger strata. In contrast, Meso- to Neoarchean ages (c. 2.65-2.80 Ga) found in the investigated samples are scarce and occur only in the SE of the studied area. They are interpreted to represent recycled parts of the Kheis Subprovince or of the Magondi Belt (Glynn 2017; Van Niekerk 2006; Fig. 1b), since both are the only Late Archean structural units in the vicinity of the study area. No older ages have been found, indicating a complete cover of the Kalahari Craton interior (Kaapvaal Shield) by younger sediments during the Mesozoic. Tonian zircon ages are scarce along the Kalahari Craton margins but may be associated with the Richtersveld Igneous Complex (Frimmel et al. 2001).

Nevertheless, all presented samples show a clear trend in their zircon age pattern from sample Nam 415 (Neu Loore fm.) towards all samples of the Waterberg and Huab Basins (Fig. 8). Sample Nam 415 features three distinct age peaks whereas the Paleoproterozoic and Mesoproterozoic age peaks thin out in all other samples. In addition, a prominent Permian age peak is present within the zircon age pattern of all samples besides Nam 415 (Fig. 8), indicating a provenance change during the Upper Triassic. Permo-Triassic zircon ages within Karoo-aged strata of the Main Karoo Basin, Congo Basin and Paraná Basin have been reported by several authors (Canile et al. 2016; Linol et al. 2016; Viglietti et al. 2018). The source of the Permian age population is somewhat enigmatic as there is no known magmatic activity of that particular age within the study area, although the Karoo-aged strata feature numerous ash beds of Upper Permian age (Fildani et al. 2009; McKay et al. 2015; Milani and De Wit 2008). McKay et al. (2015) and Rubidge et al. (2013) suggested the southern Gondwanan volcanic arc as a possible source area (Fig. 1b).

An unspecific source of six of the seven investigated Mesozoic sedimentary samples becomes apparent when 
Fig. 11 Non-metric MDS plots after Vermeesch (2013) revealing similarities between samples of this study and selected southern Gondwanan structural units and successions. The figure is based on c. 44,000 single zircon analyses compiled from 154 published studies. a Comparison of samples of this study with Mesoproterozoic and younger southern African structural units. The cited literature used for this compilation is given in the supplementary data. b Comparison of samples of this study with the southern Gondwanan Mesozoic detrital U-Pb zircon age record (Pinto et al. (2015), Alessandretti et al. (2016), Canile et al. (2016), Griffis et al. (2018), and Philipp et al. (2018) for Paraná Basin; Linol et al. (2016) and Owusu Agyemang et al. (2016) for Congo Basin; Bowden (2013), Andersen et al. (2016b), Rademan (2018), and Viglietti et al. (2018) for Karoo Basin; Bicca et al. (2018) for Moatize-Minjova Basin; Barrett et al. (2020) for Mid-Zambezi Basin). Symbol colours follow the international chronostratigraphic chart

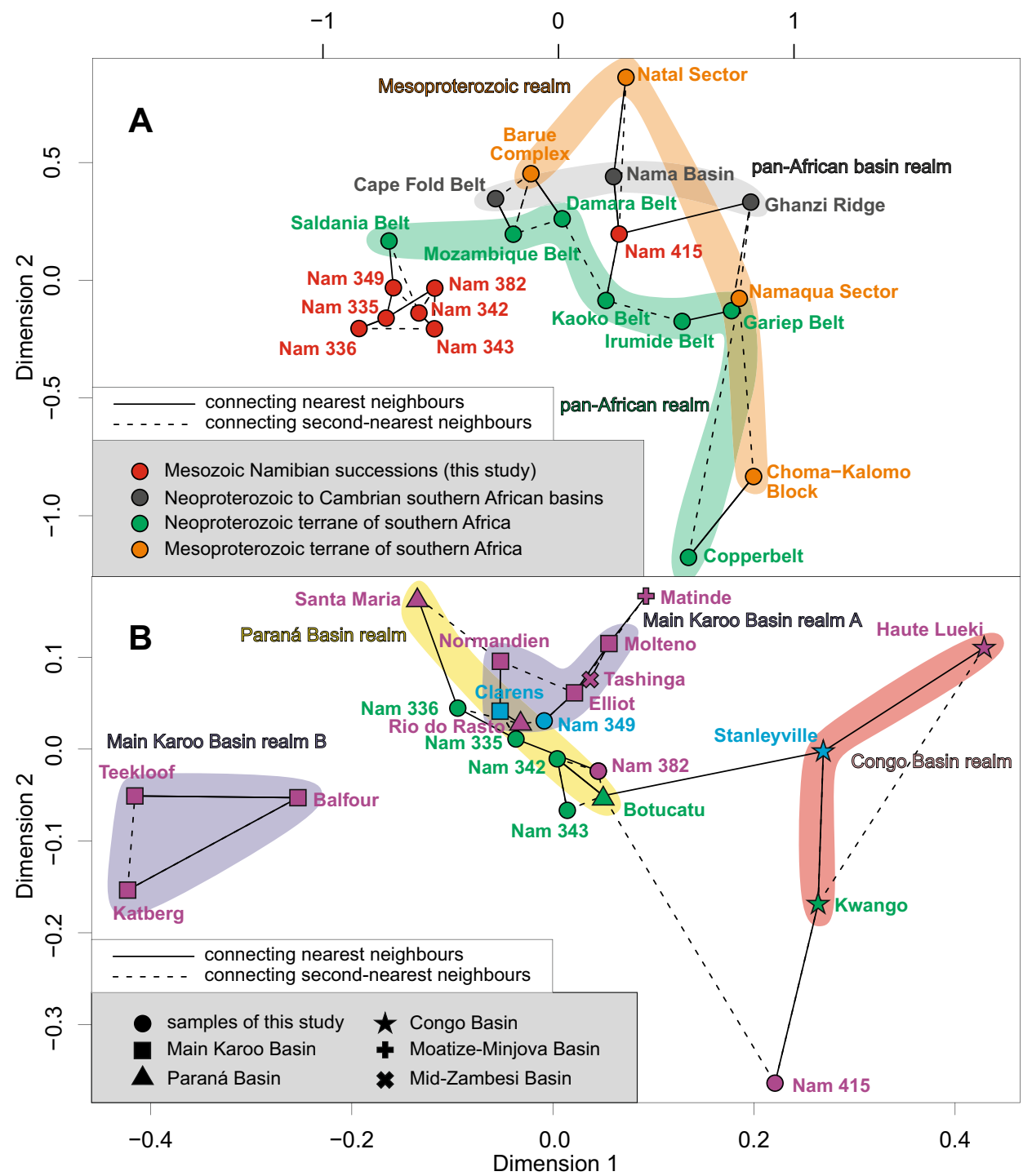

comparing the statistical dissimilarity with Mesoproterozoic and younger southern African structural units (Fig. 11a). The results show that the statistical dissimilarities are large between the samples dividing them into two groups: The first group is represented by sample Nam 415 (Neu Loore fm.) with the largest dissimilarity to the Neoproterozoic Saldania Belt and Copperbelt as well as to the Mesoproterozoic Choma-Kalomo Block (Fig. 11). The dissimilarity is smaller to the Mesoproterozoic Natal and Nama sectors and Barue Complex as well as to the Neoproterozoic Irumide and Gariep belts and to detrital successions of the Ghanzi Ridge and the Cape Fold Belt (Fig. 11a). A lowest statistical dissimilarity exists between sample Nam 415 and the Nama Basin strata (Fig. 11a). In summary, sample Nam 415 shows low dissimilarities with the majority of southern African Neoproterozoic structural units and detrital successions, implying either a derivation of the sediments of the Neu Loore from a not specified unit or it represents a mixture of several units as it plots between the Mesoproterozoic and pan-African realms (Fig. 11a). The second group comprises all investigated samples but Nam 415 and has the highest statistical dissimilarity with the Choma-Kalomo Block and the Copperbelt (Fig. 11a). A lower statistical dissimilarity is present with all of the Neoproterozoic belts, besides the Copperbelt and Saldania Belt, which is the closest statistical neighbour (Fig. 11a). Thus, the second group of samples may not be correlated with any of the older southern African units and therefore, indicates a more exotic provenance not able to be located within southern Africa. The MDS analysis of the U-Pb isotope data allows no clear assignment of either of the apparent sample groups into a respective realm. Thus, it is only possible to provide insights concerning the bedrock/proto sources of the sediments but no source-to-sink model may be applied, requiring a new approach (see further discussion). 


\section{Recycling dynamics of the Mesozoic sediments}

Recent studies conducted by Andersen et al. (2016b), Andersen et al. (2018a) and Orejana et al. (2015) concluded biased results of conventional zircon studies assuming a direct pathway of sediment source to sediment sink not taking into account repeated sedimentary recycling events obscuring such 'source-to-sink' dynamics. A similar effect has also been suggested by Vorster (2014) and Zieger et al. (2019) for the lower Karoo-aged strata (Dwyka Group) of the Main Karoo and Aranos basins.

To reveal differences in recycling history, the zircon morphology can offer valuable information concerning the duration and intensity of zircon grain transport (Gärtner et al. 2013). As with the U-Pb detrital zircon data the morphology of the investigated zircon grains also reveals a clear distinction between the crystals of the Neu Loore $\mathrm{fm}$. and the rest of the sample set (Fig. 6). The zircon grains of sample Nam 415 are smaller (Fig. 6a, b) and feature more diverse roundness values than the grains of the other samples (Fig. 6c). The variety of zircon roundness values may be due to two different reasons: (1) The transport of the material was not long and/or intense or (2) the sediments of the Neu Loore fm. were the result of a mixing of a local bedrock source with already recycled material. Both possibilities are not mutually exclusive and the obtained zircon morphologies may be the result of a combination of both processes. An apparent disparity in zircon grain roundness was also observed by Zieger et al. (2019) for the Dwyka Group sediments of the Aranos Basin. In contrast, all remaining samples show fairly rounded grains clearly indicating intensive grain/sediment movement either by transport over long distances or by permanent local sediment regrouping and movement. Nevertheless, high degrees of zircon roundness points to (re-) recycling and shows no evidence of input of fresh basement material (Zoleikhaei et al. 2016). Furthermore, the degree of roundness for zircon grains of this study are different from zircon roundness values obtained by Zieger et al. (2019) for the Dwyka Group sediments of the Aranos Basin. Simple visual inspection the ${ }_{\varepsilon} \mathrm{Hf}_{(\mathrm{t})}$ values of the Namibian and South African (Main Karoo Basin) of the detrital zircon age vs the $\mathrm{Hf}$ isotope patterns reveal an extensive similarity between both Karoo strata distribution areas (Fig. 9a, b). Due to the lack of data a similarity of the Congo and Paraná Basin successions with the Namibian and South African successions is not apparent but may not be excluded (Fig. 9). Nevertheless, a mix of all sorts of components is suggested when comparing ${ }_{\varepsilon} \mathrm{Hf}_{(\mathrm{t})}$ values of Mesozoic SW Gondwanan Karoo-aged successions (Fig. 9), showing a range of c. 25 epsilon units for all the Karoo-aged basin successions, which cannot be sourced from one basement unit alone, as distinct basement units show a narrow spread of $<5$ epsilon units (e.g. Cornell et al. 2015; Hofmann et al. 2014). The widespread of
${ }_{\varepsilon} \mathrm{Hf}_{(t)}$ values indicates a mixing of several sources, which is supported by the abundant zircon morphotypes., pointing towards different magma compositions and temperatures (Fig. 7) in the source igneous or metamorphic rocks.

The Upper Triassic Neu Loore fm. is interpreted to represent the last remains of a recycling regime characterized by mixing of freshly eroded with older recycled material, resulting in a dipolar zircon population visible by the degree of roundness of the detrital zircon grains. All other samples of the present study are interpreted to record the subsequent intensive reworking of the 'Neu Loore type' material, leading to sediment homogenization.

The sudden change in zircon provenance, which is present in all samples investigated for this study younger than the Neu Loore fm., begins in the uppermost Triassic with the sedimentation of the Omingonde $\mathrm{fm}$. and is characterized by the occurrence of Permian-aged zircon grains (Fig. 8) and the differences in the geochemical data (Fig. 10). Karooaged successions with similar age patterns have also been found in the Main Karoo Basin and in the Paraná Basin (e.g. Andersen et al. 2016b; Bowden 2013; Canile et al. 2016). Viglietti et al. (2018) and Zieger et al. (2019) showed that the Permo-Triassic ash bed material underwent no significant recycling as the Permian-aged zircon grains of these samples show an euhedral nature. In contrast, all Permianaged zircon grains investigated within the present study are not euhedral but show a high to very high grade of roundness (Fig. 6c) indicating intensive transport and reworking of the sediments.

On the base of the latter, it is possible to make some assumptions about sediment fluxes during the Mesozoic in the SW of Gondwana. As the provenance of the Neu Loore fm. (sample Nam 415) is similar to the zircon age patterns of local sources, such as the Damara Orogen and the Nama Basin (Fig. 11a) the zircon grains may not be transported very far, which is in line with their angular shape. The transport was probably induced by a river system originating from a paleohigh (Cargonian Highlands?) in the E or SE (Fig. 12a; Bordy et al. 2010). As already mentioned, the strata of the Neu Loore fm. is special as their zircon age pattern is unique in comparison to other Triassic-aged southern Gondwanan successions (Fig. 11b). Statistical dissimilarities are largest with the samples of this study, both Main Karoo Basin realms, and with the Paraná Basin realm, implying a different sedimentary history. There is a relatively low statistical dissimilarity between the Neu Loore fm. and the Kwango fm. of the Congo Basin realm (Fig. 11b). Linol et al. (2016) proposed a more local source area for the successions of the Kwango fm., which may also apply for the Neu Loore fm.

The drastic provenance change is coeval with the initial subsidence related to the opening of the Waterberg rift basin leading to the sedimentation of the Omingonde fm (Zerfass 

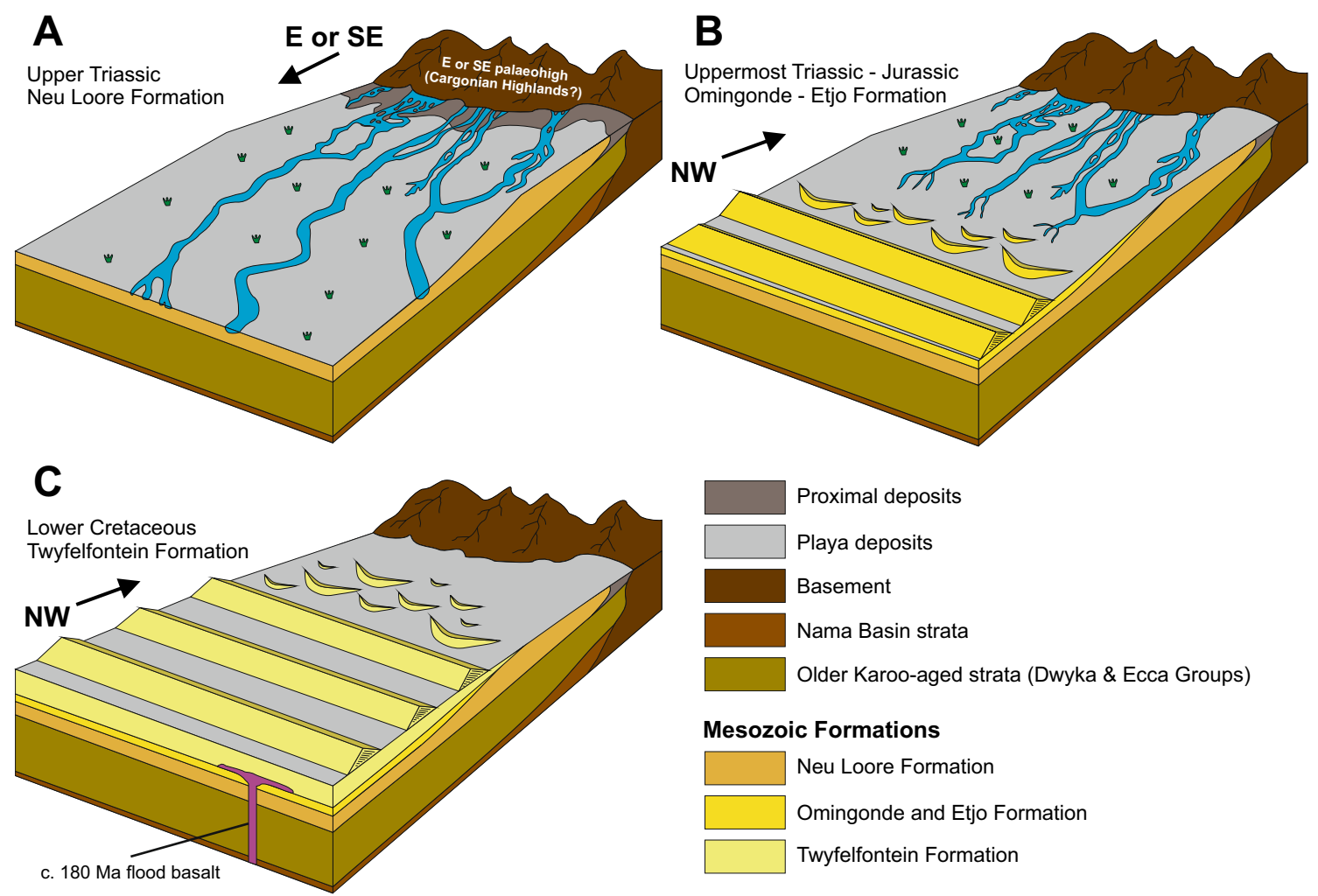

Fig. 12 Possible facies changes during the Mesozoic period (paleocurrents based on Bordy et al. 2010; Rademan 2018; and own observations). The black arrow indicates the direction of the main sediment flux. a Playa deposits and meandering rivers sourced from an eastern Paleohigh east (maybe Cargonian Highlands) during the deposi-

et al. 2005). contemporaneous to a climate and facies change (Smith and Swart 2002; Fig. 12b). Due to general desertification of SW Gondwana during uppermost Triassic to lower Jurassic, the rivers originating from the eastern paleohigh did not reach far enough (Rademan 2018). Therefore, the east directed rivers may not contribute to the provenance of the Omingonde fm. strata. The rounded nature of zircon grains of the Omingonde and Etjo fms. (Fig. 6c) most likely inherit multiple times recycled ash fall deposits sourced from the Gondwanides volcanic arc in the SE, as they are the nearest source where Upper Permian volcanism occur (e.g. Pankhurst et al. 2006; Fig. 1). Similarly to the Waterberg Basin sediments, high amounts of late Permian aged zircon grains have been found within the Upper Triassic and Jurassic successions of the Paraná and Main Karoo basins (Andersen et al. 2016b; Canile et al. 2016; Viglietti et al. 2018), which are also most likely sourced from ash fall tuffs produced by the Gondwanides volcanic arc (Castillo et al. 2016; Linol et al. 2016; Rocha-Campos et al. 2011). The material later forming the Triassic to Jurassic Waterberg and Paraná Basin sediments was transported towards the N/NE (Fig. 12; Philipp et al. 2018), and became mixed with older tion of the Neu Loore fm. in the Upper Triassic. b Transition from uppermost Triassic (Omingonde fm.) to Early Jurassic (Etjo fm.) is characterized by retreating river systems and a developing desert with sediments coming from the west. c Eolian dominated facies during the Lower Cretaceous

pan-African components (Figs. 8, 9, 10; Canile et al. 2016; Scherer and Goldberg 2007) covering major parts of SW Gondwana (Andersen et al. 2016a; Peri et al. 2016). The SW source of the sediments is also inferred by NE dip directions of the barchanoids of the Etjo fm. (Bigarella 1973). A possible genetic link between the Upper Triassic and Lower Jurassic SW Gondwanan sediments and therefore, a shared recycling history, becomes apparent when comparing statistical dissimilarities of detrital zircon age data of the investigated samples and data from other Mesozoic SW Gondwana successions: The investigated sediments show low statistic dissimilarity to the Triassic Rio do Rasto and Santa Maria fms. of the Paraná Basin realm, to the Elliot and Normandien fms. of the Main Karoo Basin realm A and to the Tashinga fm. of the Mid-Zambezi Basin (Fig. 11b). The low statistical dissimilarity observed among successions from the mid-Triassic to lower Jurassic may hint towards a sediment homogenization system from the Paraná Basin to the Mid-Zambezi Basin expanding over c. $1700 \mathrm{~km}$. The Congo Basin realm and Main Karoo Basin realm B do not overlap and therefore show a large statistical dissimilarity (Fig. 11b), suggesting different recycling histories. 
To define the timing of the sediment mixing process it is possible to determine the maximum age of deposition of the Omingonde fm., given by the youngest zircon grain with an age of $240 \pm 4 \mathrm{Ma}$ (Ladinian, Middle Triassic; Table 1) fitting well with the biostratigraphic age range proposed by Keyser (1973) between c. 241 and c. 236 Ma.

The Lower Cretaceous Twyfelfontein fm. sediments of the Huab Basin (samples Nam 335, 336, 342, 343) show somewhat similar zircon age patterns with a prominent pan-African and Permian age component (Figs. 7, 12b). The similar zircon age patterns may be explained by an erg depositional system prevailing during early Cretaceous situated in SW Gondwana (Jerram et al. 2000; Scherer and Goldberg 2007), including the areas of today's Namibia and Brazil, representing a continuation and intensification of the conditions existing during the Lower Jurassic with a prevailing NE directed paleowind pattern (Fig. 12b, c), suggested by NE to ENE dipping dune foresets (e.g. Bigarella 1973; Horsthemke 1992). Sedimentary recycling and homogenization continued together with mixing and polishing of the detrital zircon grains (Fig. 6), as the transport of the material was mostly eolian (Miller 2008). The statistical dissimilarity is very low between the Botucatu $\mathrm{fm}$. and the samples of the Twyfelfontein fm. (Fig. 11b). As the detrital zircon age patterns of the Twyfelfontain and Botucatu fms. are similar, the mid-Triassic to lower Jurassic sediment homogenization system (see discussion above) covering SE Gondwana may exist at least until the lower Cretaceous.

Comparing the detrital zircon record of all southern Gondwanan Mesozoic sediments shows that not all of them share a similar recycling history (Fig. 11b). A low statistical dissimilarity of the sediments of the Paraná Basin and the Main Karoo Basin realm A with all investigated samples besides sample Nam 415 may imply a similar sedimentary homogenization. In contrast, the successions of the Congo Basin realm and Main Karoo Basin realm B show large dissimilarities. The difference in the detrital zircon age patterns may be caused by diverse input of more local bedrock sources as it is normal in continental environments.

\section{Conclusions}

Six of the seven investigated sandstones from four Mesozoic fms. of northern Namibian cover sequences of the Karoo Supergroup and of the Etendeka Group show similar detrital zircon age components and $\mathrm{Hf}$ isotope distribution patterns, with major late Neoproterozoic to early Phanerozoic and Mesoproterozoic age clusters. These patterns are similar to the detrital zircon record of Neoproterozoic basement rocks in the region, but lacking the specific Hf isotope characteristics of bedrock sources and feature high portions of very well rounded detrital zircon grains. Therefore, the latter zircon fractions are much more likely to have been derived from Meso- to Neoproterozoic cover sequences resting on Archean to Mesoproterozoic basement as directly from firstgeneration sources. Thus, the investigated sediments carry no interpretable provenance information, hosting a more or less homogenized mixture of detritus of Neoproterozoic to Mesoproterozoic orogens denudated long before the deposition of the Karoo Supergroup successions. Additionally, late Permian detrital zircon ages have been observed in the higher parts of the succession. The Permian detrital zircon ages suggest a dominating southerly source with material transport over long distances from the southern Gondwanan margin. In most cases, these zircons are older than their host sediments, not giving any information concerning sedimentation ages.

In contrast, deduced from the detrital zircon age record, the lowermost Triassic Neu Loore fm. is characterized by recycling of local crystalline basement material, which was not transported over long distances and mixing with older sediments. The input of local basement material is also proposed by the angular morphology of the investigated zircon grains.

The U-Pb zircon age patterns and zircon grain morphology allow us a reconstruction of the paleosediment flux directions. The Neu Loore fm. featured only zircon grains older $500 \mathrm{Ma}$, making a southern source unlikely as the Gondwanides in the south of the study area produced rocks containing vast amounts of Permo-Triassic aged zircon grains. In the course of the Mesozoic evolution, these grains may got dispersed and transported towards the N/ NE by rivers and/or air. The results challenge the classical interpretations based on detrital zircon age data. At least for the Karoo-aged sediments of Namibia, the classic 'source-to-sink' model cannot be used as the zircon age pattern of the original source regions are probably obscured by intermediate storage and repeated recycling.

To reveal such dynamics it is important to combine as many analytical methods as possible. The robustness of zircon $\mathrm{U}-\mathrm{Pb}$ age combined with their zircon grain morphology, zircon grain ${ }_{\varepsilon} \mathrm{Hf}$ model ages and whole-rock geochemistry proved to be powerful tools for analysing sedimentary recycling histories.

Acknowledgements Open Access funding provided by Projekt DEAL. We appreciate long-term funding of the GeoPlasmaLab Dresden by the Senckenberg Naturforschende Gesellschaft and the Deutsche Forschungsgemeinschaft (DFG). We also thank Gabriel GutiérrezAlonso (Salamanca), Bastien Linol (Port Elizabeth), and Albrecht von Quadt (Zurich) for their thoughtful reviews of an earlier version of this manuscript. All cited $\mathrm{PhD}$ and M.Sc theses of this study are publically available via their respective university homepages, and also on request from the first author of this study (Johannes Zieger). 
Open Access This article is licensed under a Creative Commons Attribution 4.0 International License, which permits use, sharing, adaptation, distribution and reproduction in any medium or format, as long as you give appropriate credit to the original author(s) and the source, provide a link to the Creative Commons licence, and indicate if changes were made. The images or other third party material in this article are included in the article's Creative Commons licence, unless indicated otherwise in a credit line to the material. If material is not included in the article's Creative Commons licence and your intended use is not permitted by statutory regulation or exceeds the permitted use, you will need to obtain permission directly from the copyright holder. To view a copy of this licence, visit http://creativecommons.org/licenses/by/4.0/.

\section{References}

Alessandretti L, Machado R, Warren LV, Assine ML, Lana C (2016) From source-to-sink: the Late Permian SW Gondwana paleogeography and sedimentary dispersion unraveled by a multiproxy analysis. J S Am Earth Sci 70:368-382. https://doi. org/10.1016/j.jsames.2016.06.007

Andersen T, Elburg M, Cawthorn-Blazeby A (2016a) U-Pb and LuHf zircon data in young sediments reflect sedimentary recycling in eastern South Africa. J Geol Soc London 173:337-351

Andersen T, Elburg MA, Magwaza BN (2019a) Sources of bias in detrital zircon geochronology: discordance, concealed lead loss and common lead correction. Earth Sci Rev 197:102899. https ://doi.org/10.1016/j.earscirev.2019.102899

Andersen T, Elburg MA, Van Niekerk HS (2019b) Detrital zircon in sandstones from the Palaeoproterozoic Waterberg and Nylstroom basins, South Africa: Provenance and recycling. S Afr J Geol 122:79-96. https://doi.org/10.25131/sajg.122.0008

Andersen T, Elburg MA, van Niekerk HS, Ueckermann H (2018a) Successive sedimentary recycling regimes in southwestern Gondwana: evidence from detrital zircons in Neoproterozoic to Cambrian sedimentary rocks in southern Africa. Earth Sci Rev 181:43-60. https://doi.org/10.1016/j.earscirev.2018.04.001

Andersen T, Kristoffersen M, Elburg MA (2016b) How far can we trust provenance and crustal evolution information from detrital zircons? A South African case study. Gondwana Res 34:129-148. https://doi.org/10.1016/j.gr.2016.03.003

Andersen T, Kristoffersen M, Elburg MA (2018b) Visualizing, interpreting and comparing detrital zircon age and $\mathrm{Hf}$ isotope data in basin analysis-a graphical approach. Basin Res 30:132147. https://doi.org/10.1111/bre.12245

Bangert B (2000) Tephrostratigraphy, petrography, geochemistry, age and fossil record of the Ganigobis Shale Member and associated glaciomarine deposits of the Dwyka Group, Late Carboniferous, southern Africa. Unpublished Ph.D thesis, Universität Würzburg

Barrett PM, Sciscio L, Viglietti PA, Broderick TJ, Suarez CA, Sharman GR, Jones AS, Munyikwa D, Edwards SF, Chapelle KEJ, Dollman KN, Zondo M, Choiniere JN (2020) The age of the Tashinga Formation (Karoo Supergroup) in the Mid-Zambezi Basin, Zimbabwe and the first phytosaur from mainland sub-Saharan Africa. Gondwana Res 81:445-460. https://doi. org/10.1016/j.gr.2019.12.008

Bicca MM, Jelinek AR, Philipp RP, de Carvalho LC, Alkmim AR (2018) Precambrian-Cambrian provenance of Matinde Formation, Karoo Supergroup, northwestern Mozambique, constrained from detrital zircon $\mathrm{U}-\mathrm{Pb}$ age and Lu-Hf isotope data. J Afr Earth Sc 138:42-57. https://doi.org/10.1016/j.jafrearsci.2017.10.013

Bigarella JJ (1973) Paleocurrents and the problem of continental drift. Geol Rundsch 62:447-477. https://doi.org/10.1007/bf01840109
Bordy EM, Segwabe T, Makuke B (2010) Sedimentology of the Upper Triassic-Lower Jurassic (?) Mosolotsane Formation (Karoo Supergroup), Kalahari Karoo Basin, Botswana. J Afr Earth Sc 58:127-140. https://doi.org/10.1016/j.jafrearsci.2010.02.006

Bouvier A, Vervoort JD, Patchett PJ (2008) The Lu-Hf and Sm-Nd isotopic composition of CHUR: constraints from unequilibrated chondrites and implications for the bulk composition of terrestrial planets. Earth Planet Sci Lett 273:48-57. https:// doi.org/10.1016/j.eps1.2008.06.010

Bowden LL (2013) A comparative study of detrital zircon ages from river sediment and rocks of the Karoo Supergroup (Late Carboniferous to Jurassic), Eastern Cape Province, South Africa: Implications for the tectono-sedimentary evolution of Gondwanaland's southern continental margin. Unpublished Ph.D thesis, University of Johannesburg

Bullard E, Everett JE, Smith AG (1965) The fit of the continents around the Atlantic. Philos Trans R Soc Lond Ser A Math Phys Sci 258:41-51

Cahen L (1983) Le Groupe de Stanleyville (Jurassic superieur et Wealdien de l'intérieur de la République du Zaïre): Révision des connaissances. Rapport annuel du Musée Royal de l'Afrique centrale, Tervuren (Belgique), Département de Géologie et de Minéralogie, pp 73-91

Cahen L, Lepersonne J (1978) Synthèse des connaissances relatives au Groupe (anciennement Série) de la Lukuga (Permien du Zaïre). Annales du Musée Royal du Congo belge. Tervuren (Belgique) $82: 115-152$

Canile FM, Babinski M, Rocha-Campos AC (2016) Evolution of the Carboniferous-Early Cretaceous units of Paraná Basin from provenance studies based on $\mathrm{U}-\mathrm{Pb}, \mathrm{Hf}$ and $\mathrm{O}$ isotopes from detrital zircons. Gondwana Res 40:142-169. https://doi.org/10.1016/j. gr.2016.08.008

Castillo P, Fanning CM, Hervé F, Lacassie JP (2016) Characterisation and tracing of Permian magmatism in the south-western segment of the Gondwanan margin; $\mathrm{U}-\mathrm{Pb}$ age, $\mathrm{Lu}-\mathrm{Hf}$ and $\mathrm{O}$ isotopic compositions of detrital zircons from metasedimentary complexes of northern Antarctic Peninsula and western Patagonia. Gondwana Res 36:1-13. https://doi.org/10.1016/j.gr.2015.07.014

Catuneanu O, Hancox P, Rubidge B (1998) Reciprocal flexural behaviour and contrasting stratigraphies: a new basin development model for the Karoo retroarc foreland system, South Africa. Basin Res 10:417-439

Catuneanu O, Wopfner H, Eriksson PG, Cairncross B, Rubidge BS, Smith RMH, Hancox PJ (2005) The Karoo basins of south-central Africa. J Afr Earth Sc 43:211-253. https://doi.org/10.1016/j. jafrearsci.2005.07.007

Chauvel C, Lewin E, Carpentier M, Arndt NT, Marini J-C (2007) Role of recycled oceanic basalt and sediment in generating the Hf-Nd mantle array. Nat Geosci 1:64. https://doi.org/10.1038/ ngeo.2007.51

Clifford TN, Barton ES, Stern RA, Duchesne J-C (2004) U-Pb zircon calendar for Namaquan (Grenville) crustal events in the granulite-facies terrane of the O'okiep copper district of South Africa. J Petrol 45:669-691

Cornell DH, van Schijndel V, Simonsen SL, Frei D (2015) Geochronology of Mesoproterozoic hybrid intrusions in the Konkiep Terrane, Namibia, from passive to active continental margin in the Namaqua-Natal Wilson Cycle. Precambrian Res 265:166-188. https://doi.org/10.1016/j.precamres.2014.11.028

De Waele B, Fitzsimons I, Wingate M, Tembo F, Mapani B, Belousova E (2009) The geochronological framework of the Irumide Belt: a prolonged crustal history along the margin of the Bangweulu Craton. Am J Sci 309:132-187

Dickinson WR, Beard LS, Brakenridge GR, Erjavec JL, Ferguson RC, Inman KF, Knepp RA, Lindberg FA, Ryberg PT (1983) Provenance of North American Phanerozoic sandstones in 
relation to tectonic setting. Geol Soc Am Bull 94:222. https:// doi.org/10.1130/0016-7606(1983)94\%3c222:ponaps\%3e2.0.co;2

Fildani A, Weislogel A, Drinkwater NJ, McHargue T, Tankard A, Wooden J, Hodgson D, Flint S (2009) U-Pb zircon ages from the southwestern Karoo Basin, South Africa-implications for the Permian-Triassic boundary. Geology 37:719-722

Floyd P, Leveridge B (1987) Tectonic environment of the Devonian Gramscatho basin, south Cornwall: framework mode and geochemical evidence from turbiditic sandstones. J Geol Soc Lond 144:531-542

Foster DA, Goscombe BD, Newstead B, Mapani B, Mueller PA, Gregory LC, Muvangua E (2015) U-Pb age and $\mathrm{Lu}-\mathrm{Hf}$ isotopic data of detrital zircons from the Neoproterozoic Damara Sequence: Implications for Congo and Kalahari before Gondwana. Gondwana Res 28:179-190. https://doi.org/10.1016/j.gr.2014.04.011

Frei D, Gerdes A (2009) Precise and accurate in situ U-Pb dating of zircon with high sample throughput by automated LA-SF-ICPMS. Chem Geol 261:261-270. https://doi.org/10.1016/j.chemg eo.2008.07.025

Frimmel HE, Basei MAS, Correa VX, Mbangula N (2013) A new lithostratigraphic subdivision and geodynamic model for the PanAfrican western Saldania Belt, South Africa. Precambrian Res 231:218-235. https://doi.org/10.1016/j.precamres.2013.03.014

Frimmel HE, Zartman RE, Späth A (2001) The Richtersveld Igneous Complex, South Africa: U-Pb zircon and geochemical evidence for the beginning of Neoproterozoic continental breakup. J Geol 109:493-508

Frizon de Lamotte D, Fourdan B, Leleu S, Leparmentier F, de Clarens $P$ (2015) Style of rifting and the stages of Pangea breakup. Tectonics 34:1009-1029. https://doi.org/10.1002/2014tc003760

Gärtner A, Linnemann U, Sagawe A, Hofmann M, Ullrich B, Kleber A (2013) Morphology of zircon crystal grains in sedimentscharacteristics, classifications, definitions. Geologica Saxonica 59:65-73

Gärtner A, Youbi N, Villeneuve M, Linnemann U, Sagawe A, Hofmann M, Zieger J, Mahmoudi A, Boumehdi MA (2018) Provenance of detrital zircon from siliciclastic rocks of the Sebkha Gezmayet unit of the Adrar Souttouf Massif (Moroccan Sahara)-Palaeogeographic implications. C R Geosci 350:255-266. https://doi. org/10.1016/j.crte.2018.06.004

Gehrels GE, Dickinson WR, Riley BCD, Finney SC, Smith MT (2000) Detrital zircon geochronology of the Roberts Mountains allochthon, Nevada. In: Soreghan MJ, Gehrels GE (eds) Paleozoic and Triassic paleogeography and tectonics of western Nevada and Northern California, vol 347. Geological Society of America, Boulder, pp 19-42. https://doi.org/10.1130/0-8137-2347-7.19

Gerdes A, Zeh A (2006) Combined U-Pb and Hf isotope LA-(MC-) ICP-MS analyses of detrital zircons: comparison with SHRIMP and new constraints for the provenance and age of an Armorican metasediment in Central Germany. Earth Planet Sci Lett 249:4761. https://doi.org/10.1016/j.epsl.2006.06.039

Gerdes A, Zeh A (2009) Zircon formation versus zircon alterationnew insights from combined U-Pb and Lu-Hf in-situ LA-ICPMS analyses, and consequences for the interpretation of Archean zircon from the Central Zone of the Limpopo Belt. Chem Geol 261:230-243. https://doi.org/10.1016/j.chemgeo.2008.03.005

Glynn SM (2017) Geochronology and evolution of the Magondi Belt. Unpublished Ph.D thesis, University of Witwatersrand

Gradstein FM, Ogg JG, Schmitz MD, Ogg G (2012) The geologic time scale, vol 1 and 2. Elsevier, Amsterdam

Gray DR, Foster D, Meert J, Goscombe B, Armstrong R, Trouw $R$, Passchier C (2008) A Damara orogen perspective on the assembly of southwestern Gondwana. Geol Soc Spec Publ 294:257-278

Griffis NP, Montañez IP, Fedorchuk N, Isbell J, Mundil R, Vesely F, Weinshultz L, Iannuzzi R, Gulbranson E, Taboada A, Pagani
A, Sanborn ME, Huyskens M, Wimpenny J, Linol B, Yin Q-Z (2018) Isotopes to ice: Constraining provenance of glacial deposits and ice centers in west-central Gondwana. Palaeogeogr Palaeoclimatol Palaeoecol. https://doi.org/10.1016/j.palae o.2018.04.020

Grill H (1997) The Permo-Carboniferous glacial to marine Karoo record in Southern Namibia. Beringeria 19:98

Gu XX, Liu JM, Zheng MH, Tang JX, Qi L (2002) Provenance and tectonic setting of the Proterozoic turbidites in Hunan, South China: geochemical evidence. J Sediment Res 72:393-407. https ://doi.org/10.1306/081601720393

Heath D (1972) Die geologie van die sisteem karoo in die gebied Mariental-Asab, Suidwes-Afrika. Memoir Geol Surv S Afr 61:35

Hofmann M, Linnemann U, Hoffmann K-H, Gerdes A, Eckelmann K, Gärtner A (2014) The Namuskluft and Dreigratberg sections in southern Namibia (Kalahari Craton, Gariep Belt): a geological history of Neoproterozoic rifting and recycling of cratonic crust during the dispersal of Rodinia until the amalgamation of Gondwana. Int J Earth Sci 103:1187-1202. https ://doi.org/10.1007/s00531-013-0949-6

Holzförster F, Stollhofen H, Stanistreet IG (1999) Lithostratigraphy and depositional environments in the Waterberg-Erongo area, central Namibia, and correlation with the main Karoo Basin, South Africa. J Afr Earth Sc 29:105-123. https://doi. org/10.1016/s0899-5362(99)00083-4

Horsthemke E (1992) Fazies der Karoosedimente in der HuabRegion, Damaraland, NW-Namibia. Gött Arb Geol Paläont 55:1-102

Isbell JL, Cole DI, Catuneanu O (2008) Carboniferous-Permian glaciation in the main Karoo Basin, South Africa: Stratigraphy, depositional controls, and glacial dynamics. In: Resolving the Late Paleozoic ice age in time and space, vol 441. Geological Society of America Special Paper, pp 71-82

Jansson E (2010) What lies under the Kalahari sand? U/Pb dating of Dwyka tillites, South Africa. Master Thesis, University of Gotheburg

Jerram D, Mountney N, Howell J, Stollhofen H (2000) The Fossilised Desert: recent developments in our understanding of the Lower Cretaceous deposits in the Huab Basin, NW Namibia. Commun geol Surv Namibia 12:303-313

Kennedy W (1964) The structural differentiation of Africa in the PanAfrica $( \pm 500$ my) tectonic episode. 8th Annual Report of the Research Institute of African Geology, University of Leeds, pp 48-49

Keyser A (1973) A new Triassic vertebrate fauna from South West Africa. Palaeontol Afr 16:1-15

Konopásek J, Hoffmann K-H, Sláma J, Košler J (2017) The onset of flysch sedimentation in the Kaoko Belt (NW Namibia) - Implications for the pre-collisional evolution of the Kaoko-Dom Feliciano-Gariep orogen. Precambrian Res 298:220-234. https://doi. org/10.1016/j.precamres.2017.06.017

Konopásek J, Košler J, Tajčmanová L, Ulrich S, Kitt SL (2008) Neoproterozoic igneous complex emplaced along major tectonic boundary in the Kaoko Belt (NW Namibia): ion probe and LAICP-MS dating of magmatic and metamorphic zircons. J Geol Soc London 165:153-165

Lindeque A, De Wit MJ, Ryberg T, Weber M, Chevallier L (2012) Deep crustal profile across the southern Karoo Basin and Beattie Magnetic Anomaly, South Africa: an integrated interpretation with tectonic implications. S Afr J Geol 114:265-292. https:// doi.org/10.2113/gssajg.114.3-4.265

Linol B, de Wit MJ, Barton E, de Wit MJC, Guillocheau F (2016) U-Pb detrital zircon dates and source provenance analysis of Phanerozoic sequences of the Congo Basin, central Gondwana. Gondwana Res 29:208-219. https://doi.org/10.1016/j.gr.2014.11.009 
Lovecchio JP, Rohais S, Joseph P, Bolatti ND, Ramos VA (2020) Mesozoic rifting evolution of SW Gondwana: a poly-phased, subduction-related, extensional history responsible for basin formation along the Argentinean Atlantic margin. Earth Sci Rev. https://doi.org/10.1016/j.earscirev.2020.103138

Macey PH, Bailie RH, Miller JA, Thomas RJ, de Beer C, Frei D, le Roux PJ (2018) Implications of the distribution, age and origins of the granites of the Mesoproterozoic Spektakel Suite for the timing of the Namaqua Orogeny in the Bushmanland Subprovince of the Namaqua-Natal Metamorphic Province, South Africa. Precambrian Res 312:68-98. https://doi.org/10.1016/j. precamres.2018.02.026

Macey PH, Thomas RJ, Minnaar HM, Gresse PG, Lambert CW, Groenewald CA, Miller JA, Indongo J, Angombe M, Shifotoka G, Frei D, Diener JFA, Kisters AFM, Dhansay T, Smith H, Doggart S, Le Roux P, Hartnady MI, Tinguely C (2017) Origin and evolution of the $\sim 1.9 \mathrm{Ga}$ Richtersveld Magmatic Arc. SW Afr Precambrian Res 292:417-451. https://doi.org/10.1016/j.preca mres.2017.01.013

McCourt S, Armstrong R, Jelsma H, Mapeo R (2013) New U-Pb SHRIMP ages from the Lubango region, SW Angola: insights into the Palaeoproterozoic evolution of the Angolan Shield, southern Congo Craton, Africa. J Geol Soc London 170:353-363

McKay MP, Weislogel AL, Fildani A, Brunt RL, Hodgson DM, Flint SS (2015) U-PB zircon tuff geochronology from the Karoo Basin, South Africa: implications of zircon recycling on stratigraphic age controls. Int Geol Rev 57:393-410

McLennan SM, Hemming S, McDaniel DK, Hanson GN, Johnsson MJ, Basu A (1993) Geochemical approaches to sedimentation, provenance, and tectonics. In: Johnson MJ, Basu A (eds) Processes controlling the composition of clastic sediments, vol 284. Geological Society of America, Boulder, pp 21-40. https://doi. org/10.1130/SPE284-p21

Milani EJ, De Wit MJ (2008) Correlations between the classic Paraná and Cape-Karoo sequences of South America and southern Africa and their basin infills flanking the Gondwanides: du Toit revisited. Geol Soc Spec Publ 294:319-342. https://doi. org/10.1144/sp294.17

Milani EJ, Souza PA, Fernandes LA, França AB (2007) Bacia do Paraná. Boletim de Geociencias 15:265-287

Miller RM (1988) Geological Map of Namibia, Sheet 2013-Cape Cross. Geological Survey of Namibia, Windhoek

Miller RM (2008) The Geology of Namibia, Palaeozoic to Cenozoic, vol 3. Ministry of Mines and Energy, Windhoek

Milner S, Duncan A, Ewart A, Marsh J (1994) Promotion of the Etendeka Formation to Group status: a new integrated stratigraphy. Commun Geol Surv Namibia 9:5-11

Milner SC (2007) Geological Map of Namibia, Sheet 2114-Omaruru. Geological Survey of Namibia, Windhoek

Minnaar H (2011) Composition and evolution of the proterozoic Vioolsdrif batholith (including the orange river group), Northern Cape province. University of the Free State, South Africa

Moulin M, Fluteau F, Courtillot V, Marsh J, Delpech G, Quidelleur X, Gérard M, Jay AE (2011) An attempt to constrain the age, duration, and eruptive history of the Karoo flood basalt: Naude's Nek section (South Africa). J Geophys Res Solid Earth 116:B07403. https://doi.org/10.1029/2011jb008210

Nakamura N (1974) Determination of REE, Ba, Fe, Mg, Na and K in carbonaceous and ordinary chondrites. Geochim Cosmochim Acta 38:757-775. https://doi.org/10.1016/0016-7037(74)90149 $-5$

Orejana D, Merino Martínez E, Villaseca C, Andersen T (2015) Ediacaran-Cambrian paleogeography and geodynamic setting of the Central Iberian Zone: constraints from coupled U-Pb-Hf isotopes of detrital zircons. Precambrian Res 261:234-251. https://doi. org/10.1016/j.precamres.2015.02.009
Owusu Agyemang PC, Roberts EM, Jelsma HA (2016) Late JurassicCretaceous fluvial evolution of central Africa: Insights from the Kasai-Congo Basin, Democratic Republic Congo. Cretac Res 67:25-43. https://doi.org/10.1016/j.cretres.2016.06.013

Pagani MA, Taboada AC (2010) The marine upper Palaeozoic in Patagonia (Tepuel-Genoa Basin, Chubut Province, Argentina): $85 y e a r s$ of work and future prospects. Palaeogeogr Palaeoclimatol Palaeoecol 298:130-151. https://doi.org/10.1016/j.palae o.2010.08.017

Pankhurst RJ, Rapela CW, Fanning C, Márquez M (2006) Gondwanide continental collision and the origin of Patagonia. Earth Sci Rev 76:235-257

Peri VG, Naipauer M, Pimentel M, Barcelona H (2016) Eolian deposits of the southwestern margin of the Botucatú paleoerg: Reconstruction of the Gondwana landscape in Central Northern Argentina. Sed Geol 339:234-257. https://doi.org/10.1016/j.sedge o.2016.03.019

Pettersson A, Cornell DH, Moen HFG, Reddy S, Evans D (2007) Ionprobe dating of $1.2 \mathrm{Ga}$ collision and crustal architecture in the Namaqua-Natal Province of southern Africa. Precambrian Res 158:79-92. https://doi.org/10.1016/j.precamres.2007.04.006

Philipp RP, Schultz CL, Kloss HP, Horn BLD, Soares MB, Basei MAS (2018) Middle Triassic SW Gondwana paleogeography and sedimentary dispersal revealed by integration of stratigraphy and U-Pb zircon analysis: the Santa Cruz Sequence, Paraná Basin, Brazil. J S Am Earth Sci 88:216-237. https://doi.org/10.1016/j. jsames.2018.08.018

Pinto VM, Hartmann LA, Santos JO, McNaughton NJ (2015) Zircon ages delimit the provenance of a sand extrudite from the Botucatu Formation in the Paraná volcanic province, Iraí, Brazil. Anais da Academia Brasileira de Ciências 87:1611-1622

Puetz SJ (2018) A relational database of global U-Pb ages. Geosci Front 9:877-891. https://doi.org/10.1016/j.gsf.2017.12.004

Pupin J (1980) Zircon and granite petrology. Contrib Miner Petrol 73:207-220

Rademan Z (2018) Radiometric dating and stratigraphic reassessment of the Elliot and Clarens formations; near Maphutseng and Moyeni, Kingdom of Lesotho, southern Africa. Unpublished M.Sc thesis, University of Stellenbosch

Raith JG, Cornell DH, Frimmel HE, De Beer CH (2003) New insights into the geology of the Namaqua tectonic province, South Africa, from ion probe dating of detrital and metamorphic zircon. J Geol 111:347-366

Ramos VA (2008) Patagonia: a paleozoic continent adrift? J S Am Earth Sci 26:235-251. https://doi.org/10.1016/j.jsame s.2008.06.002

Ramos VA, Aleman A (2000) Tectonic Evolution of the Andes. In: Cordani UG, Milani EJ, Tomaz Filho A, Campos DA (eds) Tectonic evolution of South America. Río de Janerio, pp 635-685

Renne PR, Glen JM, Milner SC, Duncan AR (1996) Age of Etendeka flood volcanism and associated intrusions in southwestern Africa. Geology 24:659. https://doi.org/10.1130/00917613(1996)024\%3c0659:aoefva\%3e2.3.co;2

Ring U (1995) Tectonic and lithological constraints on the evolution of the Karoo graben of northern Malawi (East Africa). Geol Rundsch 84:607-625

Rocha-Campos AC, Basei MA, Nutman AP, Kleiman LE, Varela R, Llambias E, Canile FM, da Rosa OdCR (2011) 30 million years of Permian volcanism recorded in the Choiyoi igneous province (W Argentina) and their source for younger ash fall deposits in the Paraná Basin: SHRIMP U-Pb zircon geochronology evidence. Gondwana Res 19:509-523. https://doi.org/10.1016/j. gr.2010.07.003

Roser BP, Korsch RJ (1986) Determination of Tectonic Setting of Sandstone-Mudstone Suites Using $\mathrm{SiO} 2$ Content and K2O/Na2O Ratio. J Geol 94:635-650 
Ross GM, Parrish RR, Winston D (1992) Provenance and U-Pb geochronology of the Mesoproterozoic Belt Supergroup (northwestern United States): implications for age of deposition and pre-Panthalassa plate reconstructions. Earth Planet Sci Lett 113:57-76. https://doi.org/10.1016/0012-821x(92)90211-d

Rubidge BS, Erwin DH, Ramezani J, Bowring SA, de Klerk WJ (2013) High-precision temporal calibration of Late Permian vertebrate biostratigraphy: $\mathrm{U}-\mathrm{Pb}$ zircon constraints from the Karoo Supergroup, South Africa. Geology 41:363-366. https://doi. org/10.1130/g33622.1

SACS (1980) South African Commitee for Stratigraphy: Stratigraphy of South Africa. Part 1 (Comp. Kent, L.E.) Lithostratigraphy of the Republic of South Africa, South West Africa/Namibia, and the Republics of Bophuthatswana, Transkei and Venda, vol 8. Handbook of the Geological Survey of South Africa.

Sanz L-GA (2005) Pre-and post-Katangan granitoids of the Greater Lufilian Arc-geology, geochemistry, geochronology and metallogenic significance. Unpublished Ph.D thesis, University of the Witwatersrand

Scheffler K, Buehmann D, Schwark L (2006) Analysis of late Palaeozoic glacial to postglacial sedimentary successions in South Africa by geochemical proxies-Response to climate evolution and sedimentary environment. Palaeogeogr Palaeoclimatol Palaeoecol 240:184-203. https://doi.org/10.1016/j.palaeo.2006.03.059

Scherer CMS, Goldberg K (2007) Palaeowind patterns during the latest Jurassic-earliest Cretaceous in Gondwana: evidence from aeolian cross-strata of the Botucatu Formation, Brazil. Palaeogeogr Palaeoclimatol Palaeoecol 250:89-100. https://doi.org/10.1016/j.palae o.2007.02.018

Scherer CMS, Lavina ELC (2005) Sedimentary cycles and facies architecture of aeolian-fluvial strata of the Upper Jurassic Guará Formation, southern Brazil. Sedimentology 52:1323-1341. https://doi.org /10.1111/j.1365-3091.2005.00746.x

Schreiber UM (2002) Geological Map of Namibia, Sheet 2016-Otjiwarongo. Geological Survey of Namibia, Windhoek

Schreiber UM (2006a) Geological Map of Namibia, Sheet 2014-Fransfontein. Geological Survey of Namibia, Windhoek

Schreiber UM (2006b) Geological Map of Namibia, Sheet 2116-Okahandja. Geological Survey of Namibia, Windhoek

Scotese CR (2014a) Atlas of Early Cretaceous Paleogeographic Maps, PALEOMAP Atlas for ArcGIS, vol 2. The Cretaceous, Maps 23-31, Mollweide Projection, PALEOMAP Project. Evanston

Scotese CR (2014b) Atlas of Jurassic Paleogeographic Maps, PALEOMAP Atlas for ArcGIS, vol 4. The Jurassic and Triassic, Maps 32-42, Mollweide Projection, PALEOMAP Project. Evanston

Scotese CR (2014c) Atlas of Middle \& Late Permian and Triassic Paleogeographic Maps, maps 43-48 from Volume 3 of the PALEOMAP Atlas for ArcGIS (Jurassic and Triassic) and maps 49-52 from Volume 4 of the PALEOMAP PaleoAtlas for ArcGIS (Late Paleozoic), Mollweide Projection, PALEOMAP Project. Evanston

Sláma J, Košler J, Condon DJ, Crowley JL, Gerdes A, Hanchar JM, Horstwood MSA, Morris GA, Nasdala L, Norberg N, Schaltegger U, Schoene B, Tubrett MN, Whitehouse MJ (2008) Plešovice zircon-a new natural reference material for $\mathrm{U}-\mathrm{Pb}$ and $\mathrm{Hf}$ isotopic microanalysis. Chem Geol 249:1-35. https://doi.org/10.1016/j. chemgeo.2007.11.005

Smith RMH, Swart R (2002) Changing fluvial environments and vertebrate taphonomy in response to climatic drying in a Mid-Triassic rift valley fill: the Omingonde Formation (Karoo Supergroup) of Central Namibia. Palaios 17:249-267. https://doi. org/10.1669/0883-1351(2002)017\%3c0249:cfeavt\%3e2.0.co;2

Spencer CJ, Kirkland CL, Taylor RJM (2016) Strategies towards statistically robust interpretations of in situ U-Pb zircon geochronology. Geosci Front 7:581-589. https://doi.org/10.1016/j.gsf.2015.11.006
Stacey JS, Kramers JD (1975) Approximation of terrestrial lead isotope evolution by a two-stage model. Earth Planet Sci Lett 26:207-221. https://doi.org/10.1016/0012-821x(75)90088-6

Stanistreet IG, Stollhofen H (1999) Onshore equivalents of the main Kudu gas reservoir in Namibia. Geol Soc Spec Publ 153:345-365. https ://doi.org/10.1144/gsl.sp.1999.153.01.21

Stollhofen H, Stanistreet IG, Bangert B, Grill H (2000) Tuffs, tectonism and glacially related sea-level changes, Carboniferous-Permian, southern Namibia. Palaeogeogr Palaeoclimatol Palaeoecol $161: 127-150$

Turner B (1999) Tectonostratigraphical development of the Upper Karoo foreland basin: orogenic unloading versus thermally induced Gondwana rifting. J Afr Earth Sci 28:215-238

Van Niekerk HS (2006) The origin of the Kheis Terrane and its relationship with the Archean Kaapvaal Craton and the Grenvillian Namaqua Province in southern Africa. Unpublished Ph.D thesis, University of Johannesburg

Veevers JJ, Saeed A (2007) Central Antarctic provenance of Permian sandstones in Dronning Maud Land and the Karoo Basin: integration of U-Pb and TDM ages and host-rock affinity from detrital zircons. Sed Geol 202:653-676. https://doi.org/10.1016/j.sedge o.2007.07.011

Vermeesch P (2013) Multi-sample comparison of detrital age distributions. Chem Geol 341:140-146. https://doi.org/10.1016/j.chemg eo.2013.01.010

Vermeesch P, Resentini A, Garzanti E (2016) An R package for statistical provenance analysis. Sed Geol 336:14-25. https://doi. org/10.1016/j.sedgeo.2016.01.009

Viglietti PA, Frei D, Rubidge BS, Smith RM (2018) U-Pb detrital zircon dates and provenance data from the Beaufort Group (Karoo Supergroup) reflect sedimentary recycling and air-fall tuff deposition in the Permo-Triassic Karoo foreland basin. J Afr Earth Sci 143:59-66. https://doi.org/10.1016/j.jafrearsci.2017.11.006

Viglietti PA, Rubidge BS, Smith RMH (2017) New Late Permian tectonic model for South Africa's Karoo Basin: foreland tectonics and climate change before the end-Permian crisis. Sci Rep 7:10861. https ://doi.org/10.1038/s41598-017-09853-3

Viola G, Kounov A, Andreoli MAG, Mattila J (2012) Brittle tectonic evolution along the western margin of South Africa: More than 500Myr of continued reactivation. Tectonophysics 514-517:93114. https://doi.org/10.1016/j.tecto.2011.10.009

Visser JNJ (1983) An analysis of the Permo-Carboniferous glaciation in the marine Kalahari Basin, southern Africa. Palaeogeogr Palaeoclimatol Palaeoecol 44:295-315

Visser JNJ (1989) The Permo-Carboniferous Dwyka Formation of Southern Africa: deposition by a predominantly subpolar marine ice sheet. Palaeogeogr Palaeoclimatol Palaeoecol 70:377-391. https ://doi.org/10.1016/0031-0182(89)90115-6

Visser JNJ (1992) Deposition of the Early to Late Permian Whitehill Formation during a sea-level highstand in a juvenile foreland basin. S Afr J Geol 95:181-193

Visser JNJ (1995) Post-glacial Permian stratigraphy and geography of southern and central Africa: boundary conditions for climatic modelling. Palaeogeogr Palaeoclimatol Palaeoecol 118:213-243. https ://doi.org/10.1016/0031-0182(95)00008-3

Vorster C (2014) Laser ablation ICP-MS age determination of detrital zircon populations in the Phanerozoic Cape and Lower Karoo Supergroups (South Africa) and correlatives in Argentina. Unpublished $\mathrm{Ph} . \mathrm{D}$ thesis, University of Johannesburg

Williams GD, Powell CM, Cooper MA (1989) Geometry and kinematics of inversion tectonics. Geol Soc Spec Publ 44:3-15. https://doi. org/10.1144/gsl.sp.1989.044.01.02

Williamson IT (1996) The geology of the area around Mmamabula and Dibete: including an account of the Greater Mmamabula coalfield. District Memoir, vol 6. Geological Survey Botswana, Lobatse 
Winter HDLR (1984) Tectonostratigraphy, as applied to analysis of South African phanerozoic basin. S Afr J Geol 87:169-179

Zerfass H, Chemale F, Lavina E (2005) Tectonic control of the Triassic Santa Maria Supersequence of the Paraná Basin, southernmost Brazil, and its correlation to the Waterberg Basin, Namibia. Gondwana Res 8:163-176. https://doi.org/10.1016/S1342-937X(05)71115-1

Zieger J, Rothe J, Hofmann M, Gärtner A, Linnemann U (2019) The Permo-Carboniferous Dwyka Group of the Aranos Basin
(Namibia)—how detrital zircons help understanding sedimentary recycling during a major glaciation. J Afr Earth Sci. https://doi. org/10.1016/j.jafrearsci.2019.103555

Zoleikhaei Y, Frei D, Morton A, Zamanzadeh SM (2016) Roundness of heavy minerals (zircon and apatite) as a provenance tool for unraveling recycling: a case study from the Sefidrud and Sarbaz rivers in N and SE Iran. Sed Geol 342:106-117 